\title{
MÁS ALLÁ DE LA RETÓRICA DE LA REACCIÓN. ANÁLISIS ECONÓMICO DE LA DESAMORTIZACIÓN EN COLOMBIA, 1861-1888
}

Roberto Luis Jaramillo* Adolfo Meisel Roca**

Lo que no nos deja levantar el vuelo en politica, en industria y en instrucción, son las costumbres y los restos de instituciones que nos legó la España.

Manuel Murillo Toro (1859)

$\mathrm{D}$ espués de obtener la independencia, la mayoría de los países de la América hispana atravesaron una fase de estancamiento económico o tuvieron una caída del producto interno bruto que duró varias décadas (Coatsworth, 1998, 25). Colombia no fue la excepción. Diversos factores contribuyeron al pobre desempeño de las repúblicas hispanoamericanas en el medio siglo posterior a la independencia. Ante el colapso del imperio español fue necesario construir una nueva legitimidad, tarea nada fácil. Hubo gran inestabilidad política, y los enormes costos de la Guerra de Independencia contribuyeron a que sobreviniera esa contracción económica.

Además, las instituciones heredadas de la Colonia constituían una enorme traba para un crecimiento económico dinámico. Por ello, los ideólogos liberales promovieron en toda Hispanoamérica reformas para desmontar las instituciones coloniales, entre ellas el régimen fiscal, que era muy ineficiente, y las trabas a la movilidad de la tierra, el capital y la mano de obra. En Colombia, el proceso de desmonte

* Magíster en historia andina, profesor jubilado del Departamento de Historia de la Universidad Nacional, Sede de Medellín, Medellín, Colombia, [rojo@une. net.co].

** Doctor en economía, gerente del Banco de la República en Cartagena, Cartagena, Colombia, [ameisero@banrep.gov.co]. Los autores agradecen los comentarios de Carlos Marichal, Jorge Orlando Melo, María Aguilera, Jaime Bonet, Irene Salazar, Julio Romero, Joaquín Viloria y Haroldo Calvo. Una primera versión de este documento se publicó en la serie Cuadernos de Historia Económica y Empresarial del Banco de la República de Cartagena. Fecha de recepción: 20 de enero de 2009, fecha de modificación: 26 de abril de 2009, fecha de aceptación: 2 de julio de 2009 . 
tuvo tres fases. En la primera, de tono gradualista, de 1821 a 1845 , se cambió lentamente la estructura de ingresos tributarios para dar un peso creciente a los aranceles que se cobraban por las importaciones (Uribe, Meisel y Urrutia, 2001). La segunda oleada de reformas anticoloniales ocurrió entre 1845 y 1853, cuando se eliminó el estanco del tabaco, se abolió la esclavitud, se liquidaron los resguardos indígenas, se avanzó en la descentralización fiscal y se decretó la separación de potestades entre la Iglesia y el Estado. En la era del liberalismo radical (1863-1876) se acentuaron y aceleraron las reformas al sistema educativo, se desamortizaron los bienes de manos muertas, en su inmensa mayoría vinculados a la Iglesia Católica, y se crearon las bases económicas y jurídicas para el desarrollo de la banca comercial. En este trabajo se hace una valoración económica de la desamortización y se separan los bienes muebles, inmuebles y semovientes, de los censos y deudas. Además, se discute si esta reforma fue un buen negocio, algo que no se ha hecho de manera rigurosa hasta ahora. De acuerdo con el análisis de costo-beneficio que realizamos, se puede concluir que la desamortización trajo beneficios económicos para la nación, mayores que los costos.

\title{
ORÍGENES DE LA DESAMORTIZACIÓN Y LEYES QUE LA REGULARON
}

Es difícil encontrar una definición clara del término desamortización, ligado al concepto de "amortizado". Amortizar es pasar un bien a manos muertas, es decir que queda fuera del comercio. Por tanto, desamortizar es poner en circulación un bien que antes estaba muerto. El historiador del derecho Francisco Tomás y Valiente señala que la desamortización fue un

\begin{abstract}
proceso político y económico transcurrido desde finales del siglo XVIII hasta cien años después, en el cual se produjo, por medio de normas estatales y, en función de una política consciente, la conversión en bienes nacionales, de los bienes y derechos que hasta entonces habían constituido el patrimonio amortizado de diversas entidades, para enajenarlos inmediatamente a ciudadanos individuales en pública subasta (citado en De la Hera, 1999, 82).
\end{abstract}

En Colombia, el proceso de desamortización fue civil, los bienes amortizados pasaron a ser nacionales, y se vendieron en subasta pública; hay que precisar que, según la legislación canónica, los bienes vinculados a las manos muertas quedaban espiritualizados $\mathrm{y}$, por tanto, no se podían comprar ni vender; además, estaban exentos de impuestos. Las principales motivaciones económicas de estas medidas fueron de orden fiscal; al señalar que "la fé pública elije que no se 
demore por más tiempo la amortización de la deuda nacional por la venta de los bienes desamortizados", el general Tomás Cipriano de Mosquera, quien asumió la responsabilidad del proceso, reconoció que se trataba de "un arbitrio rentístico". Además, agregó: "es de conveniencia pública realizar, cuanto antes, el pensamiento social, económico i político de la desamortización" (Secretaría de Estado i Relaciones Exteriores, 1862, 371). También se buscaba dar movilidad a muchos "bienes encadenados" para que circularan libremente en el mercado. En los países católicos de Europa y América, buena parte de los bienes de manos muertas estaban controlados por entidades religiosas o eclesiásticas, y esa medida también podía tener motivaciones políticas, como debilitar a la Iglesia, porque ésta tendía a aliarse con los sectores más conservadores, y porque se quería reducir su riqueza y su influencia institucional en aspectos tales como la educación.

La Revolución Francesa decretó la desamortización el 2 de noviembre de 1789, reforma que tuvo gran influencia en los liberales hispanoamericanos (Banzant, 1977, 5). En España la desamortización se realizó en varias etapas. La primera, entre 1798 y 1808, dirigida por Manuel Godoy. Durante la guerra contra la invasión napoleónica, la administración de José Bonaparte y la de sus opositores patriotas propusieron usar este recurso fiscal. Mendizábal la realizó en 1836 con bienes del clero regular; el general Espartero la hizo en 1841 con los del clero secular, y Madoz, en 1855, con los bienes civiles y eclesiásticos, la de mayor dimensión económica (Martí, 2003).

La desamortización colombiana fue precedida por las de Paraguay, Argentina, Chile, Uruguay y México (Díaz, 1984, t. II, 444). E1 papel de la Iglesia Católica en la sociedad y la economía, junto con la forma de organización centralista o federalista del Estado, fue el origen de los mayores conflictos en la Colombia del siglo XIX. Los enfrentamientos con la Iglesia giraban alrededor de tres temas principales: la separación de la Iglesia y el Estado, el papel de la Iglesia en la economía ${ }^{1}$ y su intervención en la educación. Los miembros del ala radical del liberalismo se identificaban con el ideario clásico del laissez faire ${ }^{2}$ y defendían la separación de la Iglesia y el Estado, el

\footnotetext{
${ }^{1}$ Sobre las capellanías y los censos se legisló desde 1821, cuando se inició el proceso contra las rentas que encadenaban bienes a favor de corporaciones religiosas, especialmente. Ese proceso se acentuó y radicalizó en 1851. Ver Vélez (1891, cap. IX).

${ }^{2}$ Entre cuyos principales representantes figuraban Manuel Murillo Toro, Salvador Camacho Roldán, Santiago y Felipe Pérez, Aquileo Parra, Miguel Samper, José Eusebio Otálora, José María Rojas Garrido, Eustorgio y Januario Salgar, Fran-
} 
federalismo, el libre cambio, la banca libre, las libertades de prensa, opinión y culto, el impuesto único a la renta, el voto popular, un sistema educativo público y laico, y, por supuesto, la desamortización ${ }^{3}$. En los años de dominio radical se profundizaron reformas que debilitaron a la Iglesia Católica en varios aspectos. Se prosiguió tan firmemente la desamortización decretada en 1861 que en 1876 quedaban pocos bienes por rematar o préstamos a censo por redimir. En 1870, los radicales invitaron a una misión de nueve pedagogos alemanes para crear en cada Estado soberano una escuela normal que preparara a los maestros que darían instrucción en primaria y relevarían a los miembros del clero, que a menudo no tenían una formación académica adecuada (Rausch, 1993). Durante la Regeneración, el período de la reacción conservadora iniciado en 1886, el campo en que hubo menos retrocesos fue en el de la desamortización. Como veremos, en 1887, en el Concordato con la Santa Sede, el gobierno se comprometió a indemnizarla por los bienes expropiados, con una cifra mucho menor de lo que valían en 1860 .

A comienzos de septiembre de 1861, siete semanas después de entrar triunfante en Bogotá, el revolucionario general Tomás Cipriano de Mosquera dictó los primeros decretos sobre desamortización. Aunque estaban vigentes la Constitución de 1858 y la Confederación Granadina, Mosquera se autoproclamó, en 1860, "Presidente Provisorio de los Estados Unidos de Nueva Granada y Supremo Director de la Guerra", y, poco después de la toma de Bogotá, "Presidente Provisorio de los Estados Unidos de Colombia". Con el decreto del 9 de septiembre de 1861 se inició el proceso de desamortización. En su artículo primero dispuso:

Todas las propiedades rústicas i urbanas, derechos i acciones, capitales de censos, usufructos, servidumbres u otros bienes, que tienen o administran como propietarios o que pertenezcan a corporaciones civiles o eclesiásticas i establecimientos de educación, beneficencia o caridad, en el territorio de los Estados Unidos, se adjudican en propiedad a la Nación por el valor correspondiente a la renta neta que en la actualidad producen o pagan, calculada como rédito al 6 por 100 anual; y reconociéndose en renta sobre el Tesoro, al 6 por $100^{4}$.

cisco Eustaquio Álvarez, Manuel Ancízar, Aníbal Galindo, Felipe Zapata, Luis A. Robles, Eugenio Castilla, Modesto Garcés, César Conto y Andrés Cerón.

${ }^{3}$ Ver Jaramillo (1995). En 1853, el presidente José María Obando sancionó una ley de separación de la Iglesia y el Estado. En 1855 se aprobó una ley de libertad religiosa que declaró que no había religión del Estado, estableció el matrimonio civil obligatorio y el divorcio vincular; ver González $(1981,362)$.

${ }^{4}$ Secretaría de Estado i Relaciones Exteriores (1862, 336). La abrumadora mayoría de los préstamos a censo estaba colocada al $5 \%$. 
E1 primer intento de reforma en nuestro país fue del Secretario de Hacienda, Florentino González ${ }^{5}$, en 1847, para los préstamos a censo. Pero sólo se aceptó su redención cuando estuviera de acuerdo el censualista, lo que en la práctica la hacía casi imposible (Cruz Santos, 1965, 478-479).

La sanción legal del Congreso en 1888 al Concordato suscrito el año anterior entre el Secretario de Estado de la Santa Sede y el plenipotenciario de la República de Colombia puso fin a las reformas radicales del papel de la Iglesia en la sociedad y la economía. El artículo primero del Concordato estableció claramente las bases de la concepción de las relaciones entre la Iglesia y el Estado en el régimen de la Regeneración:

La religión Católica, Apostólica y Romana, es la de Colombia; los poderes públicos la reconocen como elemento esencial del orden social, y se obligan a protegerla y hacerla respetar, lo mismo que sus ministros, conservándola, a la vez en el pleno goce de sus derechos y prerrogativas ${ }^{6}$.

Con el Concordato se retrocedió en muchos campos en los que las reformas radicales habían avanzado en la separación de la Iglesia y el Estado siguiendo el lema de "Iglesia libre en un Estado libre". Se puso fin, por ejemplo, al matrimonio civil entre católicos, se estableció que el Presidente de la República podría recomendar candidatos a las sillas arzobispales y episcopales, y se dispuso que "la educación e instrucción pública se organizará y dirigirá en conformidad con los dogmas y la moral de la religión católica" 7 . Los artículos 22 a 29 del Concordato se refieren a aspectos relacionados con la desamortización y a las medidas para subsanar el detrimento patrimonial de la Iglesia. En este punto central no se desmontaron las reformas radicales, pues lo que se acordó fue un reconocimiento económico a la Iglesia Católica en calidad de "deuda consolidada".

\section{EL CURSO DE LA DESAMORTIZACIÓN, 1861-1888}

\section{EL PROCESO DE DESAMORTIZACIÓN}

La primera desamortización de bienes de manos muertas en la era de las reformas liberales (1849-1880) fue la que adelantó el general José Hilario López para redimir censos eclesiásticos y laicos que gravaban

\footnotetext{
${ }^{5}$ En esa época el Presidente de la Nueva Granada era el mismo general Mosquera.

${ }^{6}$ Constitución de la República de Colombia y Concordato, Bogotá, Editorial ABC, 1935, pp. 79-80.

${ }^{7}$ Ibíd., p. 81.
} 
bienes raíces rurales y urbanos del país. En 1873 el Secretario del Tesoro, Felipe Pérez, comentó:

La Ley de 31 de mayo de 1852 autorizó al poder ejecutivo para admitir en redención de censos la totalidad de los capitales impuestos a censo sobre fincas particulares o de entidades, por la mitad del valor de dicho censo (Pérez, 1873, 60) ${ }^{8}$.

E1 Estado recibía el 50\% del valor, desaparecía la deuda del propietario del bien raíz y el Estado reconocía una renta anual del 5\% a perpetuidad al propietario del censo por el 100\% del valor. Como el 50\% que se pagaba al Estado se hacía en bonos de deuda interna cuyo precio de mercado era inferior al nominal, el interés que terminaba pagando el gobierno era superior al 5\%. De acuerdo con la Memoria del Tesoro de 1873 , hasta 1861 se habían redimido censos por $\$ 1.758 .164$, pero sólo se habían recibido $\$ 432.041$. Es decir, el descuento de los bonos era del 49\%, ya que sólo había que pagar la mitad del valor del censo (ibíd.). Hacia 1861, la situación fiscal del gobierno era difícil por el alto costo del servicio de la deuda. Buena parte de los ingresos corrientes estaba comprometida de antemano con diferentes acreedores. En la Memoria sobre la Hacienda Nacional presentada al Congreso en 1861 se calculó que en el año fiscal 1861-1862 los ingresos serían de $\$ 1.824 .000$ y los egresos $\$ 2.136 .517$, para un déficit de $\$ 312.517$. Ante esa situación y para atender algunos desembolsos adicionales el Secretario de Hacienda señaló:

La suma de esta diferencia, así como el capital de deuda flotante que se amortice en el año, los pagos que se hagan por la deuda de Tesorería que se ha reconocido, y los demás gastos que formen la deuda causada por la revolución y que hayan de pagarse, se cubrirán hasta donde sea posible con el saldo a favor del Tesoro que resulte en la cuenta general, y lo que falte, tiene que saldarse necesariamente con el producto de una contribución, porque si se salda por medio de un empréstito, la situación para el Tesoro viene a ser la misma9.

Motivado por las dificultades fiscales del gobierno y por razones ideológicas (deseo de reducir la influencia de la Iglesia en la economía, la sociedad y la política, y percepción de que era necesario para mejorar la circulación de la propiedad raíz y la eficiencia en su asignación), el gobierno del general Tomás Cipriano de Mosquera dictó el decreto de desamortización del 9 de septiembre de 1861.

\footnotetext{
${ }^{8}$ En 1847, el Secretario de Hacienda Florentino González propuso la redención de los censos. El Congreso sólo la aceptó con el consentimiento del censualista. Salvador Camacho Roldán opinó que por esa razón fue prácticamente imposible hacer las redenciones (Cruz Santos, 1965, 478-479).

${ }^{9}$ Memoria sobre la Hacienda Nacional de la Nueva Granada presentada al Congreso de 1861, Imprenta de la Nación, 1861, p. 50.
} 
Uno de los secretarios del Tesoro que adelantó la desamortización en sus primeros años fue el joven cartagenero Rafael Núñez, uno de los pocos individuos que estuvo dispuesto a aceptar un cargo que acarrearía la excomunión de la Iglesia Católica ${ }^{10}$. En una circular del 14 de junio de 1862, Núñez explicó uno de los motivos más importantes que tuvieron los liberales para llevar a cabo la desamortización de los bienes de manos muertas:

\begin{abstract}
Aquí no se trata solamente de sacar a la vida y a la circulación una masa considerable de valores inertes; ni se trata tampoco, además de lo dicho, de amortizar la deuda pública, lo cual era más todavía: aquí, por la índole de los precedentes, porque se trabaja en suelo eminentemente fértil y a la luz de una época más adelantada; aquí, repito, se trata de resolver con la desamortización, hasta donde es posible, el arduo e inmenso problema de la distribución equitativa de la propiedad, sin perjuicios de ningún derecho individual anterior (Del Castillo, 1971, 52).
\end{abstract}

Para lograrlo, se tomaron varias medidas. La primera fue subdividir las propiedades para vender unidades más pequeñas. Con el mismo objetivo de democratizar la propiedad se dieron plazos para los pagos y se suprimió la fianza personal (ibíd., 53). Sin embargo, en las discusiones iniciales sobre la desamortización el tema de la redistribución de la tierra no fue central. Por ejemplo, en el discurso de instalación de la Convención Constituyente de Rionegro el general Mosquera se refirió a los problemas fiscales como principal motivo para esta reforma y resaltó:

que no se varíe en nada el decreto sobre crédito público i el de desamortización de bienes de manos muertas. Con ellos, el establecimiento de un Banco de depósito, emisión i descuento i la prohibición absoluta al Poder Ejecutivo de pagar un interés mayor del medio por ciento mensual en los contratos que haga, con las mejoras del sistema de aduanas i administración de salinas, i los bienes que forman el fondo común de los Estados Unidos, bien puede la Nación saldar todas sus cuentas (Mosquera, 1863, 78).

Incurren en un error los historiadores que han sostenido que la desamortización buscaba dar "la tierra a los que la trabajen y la hagan producir", cuando se trataba de un asunto fiscal y de poner a circular en el mercado bienes muertos inmuebles, muebles o censos (Tirado, 1988, 151). La desamortización de 1861 expropió todos los bienes raíces, semovientes y censos pertenecientes a las entidades religiosas

${ }^{10}$ De acuerdo con Indalecio Liévano, la Secretaría del Tesoro se ofreció a Rafael Núñez después de que al menos veinte figuras del Partido Liberal no la aceptaron $(1968,51)$. Núñez fue nombrado Director Nacional de Crédito a partir del 25 de julio de 1861. Según Pablo Arosemena, el redactor del decreto de desamortización del 9 de septiembre de 1861 fue Rafael Núñez; luego, el 13 de diciembre de 1861, pasó a ser Secretario de Hacienda, y el 8 de junio de 1862, asumió como Secretario del Tesoro. En todos estos cargos defendió con ahínco la desamortización (Del Castillo, 1971, 264-265). 
controladas por la Iglesia Católica para subastarlos entre el público. El Estado recibía los pagos de los bienes subastados en bonos y diversos instrumentos de deuda pública (como vales flotantes y vales de manumisión), aunque el 10\% del pago de los censos debía ser en efectivo $^{11}$. Se suponía que con los recursos obtenidos se amortizaría la deuda interna, que el $1 .^{\circ}$ de septiembre de 1860 era de $\$ 6.007 .796^{12}$. La Nación compensaría a la Iglesia Católica reconociéndole una suma anual a perpetuidad como pago por los "bienes, valores y fincas incautados". Por ejemplo, hasta fines de 1872 se habían redimido censos por un valor nominal de $\$ 6.802 .433$ y había ingresado por ese concepto una suma de $\$ 2.449 .748$, pues los bonos de deuda pública interna tenían un descuento en el mercado. Es decir, es como si se hubiera obtenido un préstamo con un interés del 7,2\% anual. Hasta comienzos de la década de 1860, el sistema de crédito se basaba en préstamos hipotecarios, o censos, respaldados con bienes raíces urbanos o rurales. Los censos podían ser redimibles o no, y la mayoría estaban ligados a corporaciones controladas por la jerarquía católica, cuyo interés corriente era del 5\%. Además de otorgar a censo, las corporaciones católicas y el clero recibían ingresos por capellanías ${ }^{13}$. Casi todas las capellanías y buena parte de los préstamos a censo otorgados por razones de piedad o por entes religiosos eran irredimibles. Por ello, la mayoría de las propiedades afectadas con esos gravámenes perdían movilidad en el mercado. Durante todo el siglo XIX republicano, especialmente después de 1849, las relaciones entre la Iglesia y el Estado fueron un asunto que generó las mayores controversias entre los actores políticos. El antagonismo entre la Iglesia y el Partido Liberal, en especial con el ala radical, llegó a su apogeo en los primeros años de vigencia de la Constitución de 1863. Como se mencionó, los tres temas que mayor distanciamiento causaron entre la Iglesia y los liberales fueron la desamortización, el derecho de tuición de cultos y la reforma educativa de 1871, que hacía obligatoria la escuela primaria y dejaba la enseñanza religiosa sólo para los alumnos cuyos padres la solicitaran.

\footnotetext{
${ }^{11}$ Por decreto del 12 de junio de 1862, en la venta de bienes raíces también era necesario cancelar el 10\% del valor en efectivo (Restrepo, 1883, 389).

${ }^{12}$ Informe del Secretario del Tesoro al Congreso de 1865, Imprenta Echeverría Hermanos, Bogotá, 1865, p. 15.

${ }^{13}$ Ver Colmenares (1974). Las capellanías eran préstamos a censos constituidos a favor de la Iglesia por familiares de una persona fallecida o mediante testamento de la persona fallecida para pagar misas por el alma del beneficiario con los intereses.
} 
Estas reformas llevaron a una polarización ideológica sin precedentes en la historia de la joven república. En 1862 un diplomático norteamericano residenciado en Bogotá señaló:

La guerra se ha vuelto prácticamente una de religión; los Liberales contra la Iglesia y el fanatismo más intenso contra cualquier cosa que ellos propongan $^{14}$.

A pesar de la oposición contra la desamortización, de las dificultades intrínsecas a un proceso tan complejo y de la debilidad del Estado en esa época, la venta de los bienes muertos avanzó con celeridad admirable. En 1863 Miguel Chiari, un político conservador, se refirió a la rapidez del proceso desamortizador:

dos largos i laboriosos años, en los cuales, entre otros acontecimientos, habiase consumado el de los remates de los bienes, que se han arrebatado a las manos muertas que siempre viven, para darlo a las manos vivas que morirán (Chiari, 1863, 13).

E1 31 de diciembre de 1864 se habían vendido bienes raíces, muebles y semovientes y redimido censos por un valor de $\$ 2.335 .785$ (cuadro 1). En los cuatro años siguientes se obtuvieron ingresos por más de $\$ 7.000 .000$, es decir, ese fue el período de mayor movimiento relativo. La cifra alcanzada en 1881 era prácticamente igual al valor total de lo redimido y lo rematado, pues en ese año quedaban por rematar bienes por un valor de $\$ 541.701$ (Pérez, 1883, 266).

Cuadro 1

Valor acumulado de la redención de los bienes de manos muertas Bienes raíces, censos y deudas, bienes muebles y semovientes (Pesos corrientes)

\begin{tabular}{lr}
\hline Acumulado hasta & \multicolumn{1}{c}{ Valor } \\
\hline 1864 (31 de diciembre) & 2.335 .785 \\
1866 (31 de agosto) & 6.761 .975 \\
1868 (31 de diciembre) & 9.442 .156 \\
1881 & 15.362 .429 \\
\hline
\end{tabular}

Fuente: Ajente General de Bienes Desamortizados, varios números; Pérez $(1883,266)$.

Uno de los problemas que se presentó durante el proceso de desamortización fue el ocultamiento de bienes eclesiásticos, a través de figuras como el testaferrato. Las autoridades intentaron eliminar esa práctica ofreciendo recompensas a los ciudadanos que denunciaran la existencia de estos bienes. En 1864 las autoridades calcularon que los bienes ocultos tenían un valor cercano a $\$ 1.900 .000$ (cuadro 2). Se suponía que los bienes ocultos tenían un mayor valor en el Cauca

${ }^{14}$ Shaw $(1941,587)$. Un ejemplo de la discusión de estos tres temas, por un contemporáneo que argumentó sus puntos de vista con gran pasión desde la "retórica de la reacción”, es Juan Pablo Restrepo (1885). 
y en Antioquia, de $\$ 900.000$. E1 Secretario de Hacienda de la época se quejó en los siguientes términos:

En Antioquia las ocultaciones han sido mucho más fáciles, y los empleados del ramo han tenido poco tiempo y ninguna cooperación activa del gobierno seccional para lo relacionado con el perfeccionamiento de los inventarios; no habiéndose podido conseguir iniciarlos siquiera en algunos distritos por falta de empleados ${ }^{15}$.

Rafael Núñez afirmó en 1879 que en el Estado de Antioquia “jamás se realizó la desamortización”, y aunque exageraba, dejó constancia del desánimo de los antioqueños para aplicar la desamortización; lo demás corrió por cuenta del ocultamiento de bienes (Núñez, 1888).

El cálculo de cerca de $\$ 1.900 .000$ en bienes ocultos parece razonable a la luz de los desarrollos posteriores. Hasta 1881 se habían obtenido $\$ 491.936$ por ingresos de bienes ocultos (Pérez, 1883, 266). Los bienes denunciados se vendían por el avalúo, normalmente entre un $30 \%$ y un $50 \%$ inferior al valor de los remates. Si esos bienes se hubieran rematado, su precio de venta habría sido de $\$ 1.000 .000$ a $\$ 1.500 .000$, de modo que las cifras del cuadro 2 son cercanas a la realidad. La clasificación de los bienes desamortizados en raíces y censos y deudas fue más o menos equivalente en valor. En el cuadro 3 se observa que, entre los bienes inscritos hasta el 31 de diciembre de 1868 , los bienes raíces y censos y deudas tenían un valor similar, $\$ 5.881 .048$ los primeros y $\$ 5.902 .832$ los segundos. Los bienes muebles y los semovientes sólo representaban el 2,2\% del total.

Cuadro 2

Valor estimado de los bienes de manos muertas ocultos, diciembre de 1864 (Pesos corrientes)

\begin{tabular}{lr}
\hline Estado & Valor \\
\hline Cauca & 500.000 \\
Antioquia & 400.000 \\
Bogotá & 200.000 \\
Cundinamarca & 200.000 \\
Tolima & 200.000 \\
Santander & 150.000 \\
Boyacá & 100.000 \\
Bolívar & 100.000 \\
Panamá & 50.000 \\
Total & 1.900 .000 \\
\hline
\end{tabular}

Fuente: Memoria del Secretario de Hacienda y Fomento del Presidente de la Unión, Bogotá, Imprenta H. Andrade, 1880, pp. 15-16.

\footnotetext{
${ }^{15}$ Informe del Secretario de Hacienda y Fomento al Presidente de la Unión, p. 15.
} 
Cuadro 3

Bienes raíces, muebles, semovientes, censos y deudas

Inscritos hasta el 31 de diciembre de 1868

(Pesos corrientes)

\begin{tabular}{lrrrrr}
\hline $\begin{array}{l}\text { Capital de la } \\
\text { Unión y } \\
\text { los Estados }\end{array}$ & Bienes raíces & $\begin{array}{l}\text { Censos y } \\
\text { deudas }\end{array}$ & $\begin{array}{c}\text { Muebles y } \\
\text { semovientes }\end{array}$ & \multicolumn{1}{c}{ Totales } & \multicolumn{1}{c}{$\%$} \\
\hline Bogotá & $3.352 .473,40$ & $1.208 .253,00$ & $92.012,00$ & $4.652 .738,40$ & 38,63 \\
Antioquia & $87.407,70$ & $701.899,20$ & 202,40 & $789.509,30$ & 6,56 \\
Bolívar & $256.590,50$ & $522.367,15$ & $4.996,60$ & $783.954,25$ & 6,51 \\
Boyacá & $517.395,10$ & $528.468,50$ & $5.938,20$ & $1.051 .801,80$ & 8,73 \\
Cauca & $547.970,15$ & $1.198 .397,95$ & $14.936,35$ & $1.761 .304,45$ & 14,62 \\
Cundinamarca & $262.694,00$ & $354.420,20$ & $13.386,80$ & $630.501,00$ & 5,24 \\
Magdalena & $9.056,50$ & $72.345,50$ & $4.560,00$ & $85.962,00$ & 0,71 \\
Panamá & $188.964,15$ & $443.850,20$ & $6.727,80$ & $639.542,15$ & 5,31 \\
Santander & $498.230,10$ & $528.468,50$ & $8.402,85$ & $1.035 .101,45$ & 8,59 \\
Tolima & $160.267,15$ & $344.362,30$ & $108.469,60$ & $613.099,05$ & 5,09 \\
Total & $5.881 .048,75$ & $5.902 .832,50$ & $259.632,6012.043 .513,85$ & 100,00 \\
\hline
\end{tabular}

Fuente: Ajente General de Bienes Desamortizados, Bogotá, Imprenta de Gaitán, 1869, cuadro 3; cálculos de los autores.

\section{Mapa 1}

Bienes desamortizados inscritos hasta el 31 de diciembre de 1868 (Pesos corrientes)

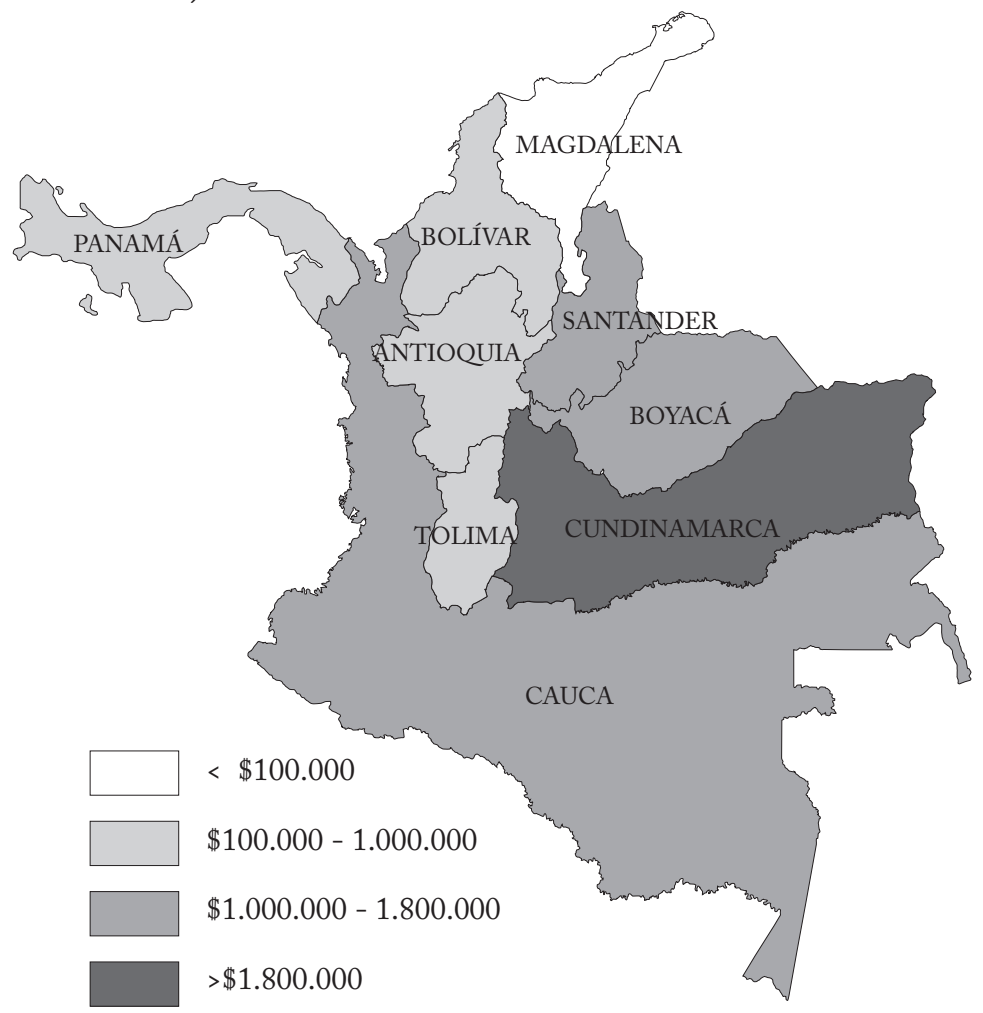

REVista DE ECONOMíA INSTITUCIONAL, VOL. 11, N. 20, PRIMER SEMESTRE/2009, PP. 45-81 
Mapa 2

Bienes desamortizados per cápita inscritos hasta el 31 de diciembre de 1868 (Pesos corrientes)

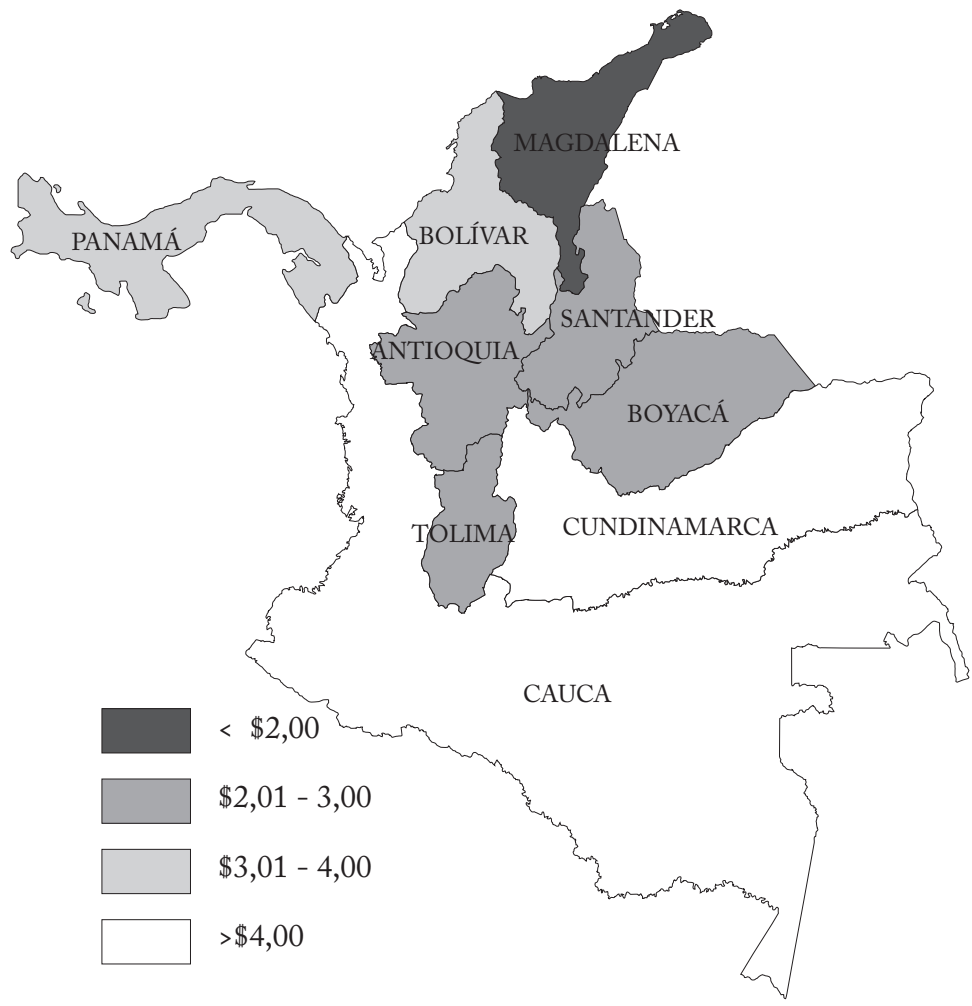

Fuente: cuadro 3; cálculos de los autores.

La distribución por estados de los bienes inscritos, a 31 de diciembre de 1868, muestra que donde más bienes muertos existían era en Bogotá y en el Cauca, que acumulaban el 53,5\% de los bienes inscritos aunque tenían cerca de una cuarta parte de la población nacional.

En la década de 1860 el valor de los bienes de manos muertas en cada estado estaba relacionado con la fortaleza económica relativa que en los tiempos anteriores había tenido la Iglesia Católica en cada uno de ellos. Un indicador de la importancia territorial de la Iglesia es el número de eclesiásticos y religiosos que había en cada sección del país, información que figura en el censo de población de 1851 . El coeficiente de correlación entre el porcentaje de eclesiásticos y religiosos que había en un estado y la participación porcentual en el valor de los bienes inscritos en 1868 para su desamortización es de 0,80. Magdalena tenía el menor porcentaje de eclesiásticos del país, 3,8\%, y el menor valor porcentual de los bienes inscritos para 
desamortización, 0,7\%. Mientras que el Cauca tenía el 27,5\% de los eclesiásticos y el 14,6\% de los bienes inscritos.

La distribución de las diferentes clases de bienes eclesiásticos era muy desigual. Mientras que en Bogotá el valor de los bienes raíces superaba ampliamente a los censos y deudas (cuadro 3), en el resto del país ocurría lo contrario. E1 57,0\% de los bienes raíces inscritos se ubicaba en Bogotá, a la que seguía el Cauca con el 9,3\%. La distribución de los censos y deudas era más balanceada: Bogotá tenía el 20,5\% del valor total y el Cauca el 20,3\%. La distribución per cápita era similar: Bogotá y el Cauca tenían bienes inscritos por más de cuatro pesos per cápita, el Magdalena por menos de un peso per cápita (mapa 2); Bolívar y Panamá tenían entre tres y cuatro pesos, y Antioquia, Boyacá, Santander y Tolima, entre dos y tres pesos por habitante. De acuerdo con Sergio Uribe, los bienes raíces desamortizados en Bogotá hasta 1870 , por un valor de $\$ 1.921 .000$, representaban el $17,7 \%$ del valor total de la finca raíz de la capital en 1863 (Uribe, 1976, 82).

La mayoría de los bienes raíces ya habían sido rematados en 1876. En poder del gobierno sólo quedaban 162 bienes, estimados en $\$ 247.428$ (cuadro 4); los de más valor estaban en el Cauca y en Panamá. E1 valor de los censos era un poco mayor, aunque faltaba información de Panamá, Cauca y Magdalena. El total de bienes ascendía a $\$ 888.871$. El avance de la desamortización se hizo muy difícil en la década de 1870 debido al éxito de los años anteriores. En 1871, el Secretario del Tesoro señaló las tres principales dificultades para seguir adelantando la desamortización: 1) los bienes que quedaban estaban muy diseminados y tenían poco valor; 2) en los estados se habían eliminado las agencias de desamortización y esas funciones se había asignado a la Tesorería, cuyos funcionarios estaban ocupados en sus tareas habituales, y 3) la legislación vigente, que hacía difícil vender un bien raíz por menos de la quinta parte de su avalúo, una vez incluido el descuento de los bonos ${ }^{16}$. La desamortización se llevó a cabo principalmente entre 1861 y 1877 . En este último año se dictó la ley 8. ${ }^{\mathrm{a}}$ que "declaró cancelada toda la renta nominal perteneciente a las iglesias, cofradías, archicofradías, patronatos y capellanías y, en general, a todas las entidades religiosas o eclesiásticas de cualquier clase y denominación que sean" (Vélez, 1891, 134).

$\mathrm{El}$ proceso fue especialmente intenso entre 1862 y 1871 , cuando se redimió y enajenó el $86 \%$ de los bienes inscritos, tal como se deduce del cuadro 5 .

\footnotetext{
${ }^{16}$ Memoria del Secretario del Tesoro y Crédito Nacional al Congreso de 1871, Bogotá, 1871 .
} 
Cuadro 4

Existencia de bienes desamortizados por redimir y rematar

Hasta $1 .^{\circ}$ de enero de 1876 (Pesos corrientes)

\begin{tabular}{|c|c|c|}
\hline & Valor & $\begin{array}{l}\text { Número } \\
\text { de bienes }\end{array}$ \\
\hline \multicolumn{3}{|l|}{ Finca raíz } \\
\hline Bolívar & $4.400,00$ & 15 \\
\hline Bogotá & $37.642,00$ & 49 \\
\hline Cauca & $112.037,80$ & 29 \\
\hline Cundinamarca & $1.600,00$ & 2 \\
\hline Magdalena & 104,00 & 4 \\
\hline Panamá & $70.001,70$ & 16 \\
\hline Santander & $9.308,70$ & 29 \\
\hline Tolima & $12.334,70$ & 18 \\
\hline Subtotal & $247.428,90$ & 162 \\
\hline \multicolumn{3}{|c|}{ Muebles y semovientes } \\
\hline Bolívar & 0,00 & 10 \\
\hline Bogotá & 74,20 & 30 \\
\hline Cauca & 739,40 & 37 \\
\hline Cundinamarca & $3.034,80$ & 431 \\
\hline Magdalena & 0,00 & 0 \\
\hline Panamá & $3.710,00$ & 460 \\
\hline Santander & 394,70 & 25 \\
\hline Tolima & 218,00 & 25 \\
\hline Subtotal & $8.171,10$ & 1.108 \\
\hline \multicolumn{3}{|l|}{ Censos y deudas } \\
\hline Antioquia & $97.384,93$ & n.d. \\
\hline Bolívar & $98.510,18$ & n.d. \\
\hline Boyacá & $160.750,20$ & n.d. \\
\hline Cundinamarca & $108.696,47$ & n.d. \\
\hline Santander & $110.071,32$ & n.d. \\
\hline Tolima & $57.858,35$ & n.d. \\
\hline Subtotal & $633.271,45$ & \\
\hline \multicolumn{3}{|l|}{ Total bienes } \\
\hline Antioquia & $97.384,93$ & \\
\hline Bolívar & $102.910,18$ & \\
\hline Bogotá & $37.716,20$ & \\
\hline Boyacá & $160.750,20$ & \\
\hline Cauca & $112.777,20$ & \\
\hline Cundinamarca & $113.331,27$ & \\
\hline Magdalena & 104,00 & \\
\hline Panamá & $73.711,70$ & \\
\hline Santander & $119.774,72$ & \\
\hline Tolima & $70.411,05$ & \\
\hline Total & $888.871,45$ & \\
\hline
\end{tabular}

Nota: falta la información de censos y deudas de los estados de Cauca, Magdalena y Panamá, que no la habían enviado.

Fuente: Ajente General de Bienes Desamortizados (1876, 9 y anexos).

El abogado y geógrafo Felipe Pérez estaba familiarizado con la desamortización, pues fue Secretario del Tesoro en la segunda administración de Manuel Murillo Toro (1872-1874) ${ }^{17}$. Según él, para medir

${ }^{17}$ Felipe Pérez (1836-1891) fue uno de los principales miembros del Olimpo Radical, el sector del Partido Liberal que dominó la vida política nacional entre 1863 y 1875 y realizó reformas sustanciales a la educación, la economía y 
el valor total de los bienes desamortizados, a los casi $\$ 15$ millones obtenidos por remates hasta 1881, habría que sumar el valor de los bienes que la Nación tomó para su uso o que había entregado a los estados y a instituciones de beneficencia y educación, cuyo valor calculó en $\$ 5$ millones, lo que elevó el valor final de la desamortización a $\$ 20$ millones. En una relación de diez de los bienes apropiados por la Unión para su uso, Alberto Pardo estimó su valor total en \$424.000 (Pardo, 1972, cuadro 134B); aunque omitió algunos, como el Convento de la Merced de Cartagena que se cedió al Estado de Bolívar, el terreno del Monasterio de La Encarnación que se cedió a Popayán, y el edificio del Convento de Santo Domingo en Tunja, que se dio al Estado de Boyacá1 ${ }^{18}$.

Cuadro 5

Bienes desamortizados hasta 1881

(Pesos corrientes)

Censos redimidos hasta 1871

Deudas a plazo pagadas

Bienes raíces rematados

Muebles y semovientes vendidos

Bienes ocultos

Recaudado 1871 a 1881

Producto en dinero

3.677 .021

377.671

7.478 .574

106.098

491.936

2.231 .129

Existencias sin rematar

1.000 .000

541.701

Total

15.904 .130

Nota: Pérez calculó en $\$ 20.000 .000$ el valor de los bienes desamortizados, luego de incluir los bienes raíces que la Nación había tomado para su uso o entregado a instituciones.

Fuente: Pérez $(1883,266)$.

\section{ANÁLISIS DE LOS CENSOS REDIMIDOS, 1862-1873}

Cuando se refieren a la desamortización, muchos autores sólo tienen en cuenta la enajenación de bienes raíces. Por ejemplo, Luis Ospina Vásquez menciona el efecto fiscal y la distribución de la tierra desamortizada, pero no menciona sus consecuencias sobre el sistema de crédito $^{19}$. E1 desconocimiento de la redención de los censos es sorprendente si se tiene en cuenta que su valor fue similar al de la finca raíz desamortizada, y que esos inmuebles urbanos y rurales recobraron su movilidad. Su eliminación fue, además, un estímulo

la sociedad colombianas bajo el influjo de las ideas del liberalismo clásico. Era hermano de Santiago Pérez, otro miembro destacado del Olimpo Radical, que fue Presidente de la República de 1874 a 1876; ver Rodríguez (1950, 219-220).

${ }^{18}$ Cruz Santos $(1965,488)$.

${ }^{19}$ Ospina $(1974,288)$. Otro historiador que equipara la desamortización con la enajenación de los bienes raíces es Álvaro Tirado (1988, 174-178). 
esencial para el surgimiento de los bancos en Colombia a partir de la década de 1870.

Cuadro 6

Número y valor de los censos redimidos, 1862-1873

(Pesos corrientes)

\begin{tabular}{lrr}
\hline Estados & $\begin{array}{c}\text { Número de } \\
\text { bienes }\end{array}$ & \multicolumn{1}{c}{ Valor } \\
\hline Antioquia & 1.970 & 633.817 \\
Bolívar & 494 & 418.195 \\
Boyacá & 296 & 243.193 \\
Cauca & 1.023 & 794.249 \\
Cundinamarca & 848 & 1.145 .327 \\
Magdalena & 30 & 17.786 \\
Panamá & 430 & 386.912 \\
Santander & 551 & 208.611 \\
Tolima & 277 & 198.155 \\
n.d. & 275 & 264.413 \\
Total & 6.194 & 4.310 .657 \\
\hline
\end{tabular}

Nota: en la información de Cundinamarca también se incluye la de Bogotá; n.d.: no disponible.

Fuente: Ajente General de Bienes Desamortizados, varios años; cálculos de los autores.

Con base en los informes de la Ajencia General de Bienes Desamortizados se construyó una base de datos que relaciona un total de 6.194 bienes sobre los que recaían censos por un valor de $\$ 4.310 .657$ (cuadro 6). Cada préstamo tiene el nombre del censatario (deudor), el interés anual, la ubicación del bien hipotecado, el beneficiario del préstamo y el valor del capital acensuado, y la fecha de redención. Por ejemplo, el 31 de agosto de 1865, Leopoldo Borda redimió un censo por $\$ 6.400$, al $5 \%$, sobre una casa ubicada en la capital, en la Calle $1^{\mathrm{a}}$ de la Carrera de Bolivia, cuyo beneficiario era el Monasterio Santa Inés de Bogotá. Para redimir un censo se pagaba el 10\% en dinero efectivo, y el $90 \%$ restante se podía pagar en bonos de deuda pública emitidos por el Estado. Como el valor de mercado de esos bonos normalmente era inferior al valor nominal, los censualistas finalmente pagaban una suma algo menor al valor nominal que entregaban. Las cuentas son un tanto confusas, pues parece que en la contabilidad de la Ajencia General de Bienes Desamortizados a veces no se registró el valor nominal de los bonos recibidos sino el valor del censo. Por esta razón, no habría que hacer un descuento sobre el valor registrado de los censos para llegar al valor real de mercado. Por ejemplo, para los censos redimidos hasta 1868 , cuyo principal era de $\$ 4.544 .093$, se recibieron bonos por un valor nominal de $\$ 7.500 .000$. Como se recibía el $10 \%$ en efectivo, en este caso $\$ 454.409$, esos bonos sirvieron 
para redimir $\$ 4.089 .684$, con un descuento del $45,5 \%$ sobre el valor nominal. Es decir, la Nación recibió el 64,5\% del valor del remate ${ }^{20}$.

Mapa 3

Valor de los censos y deudas redimidas, 1862-1873 (Pesos corrientes)

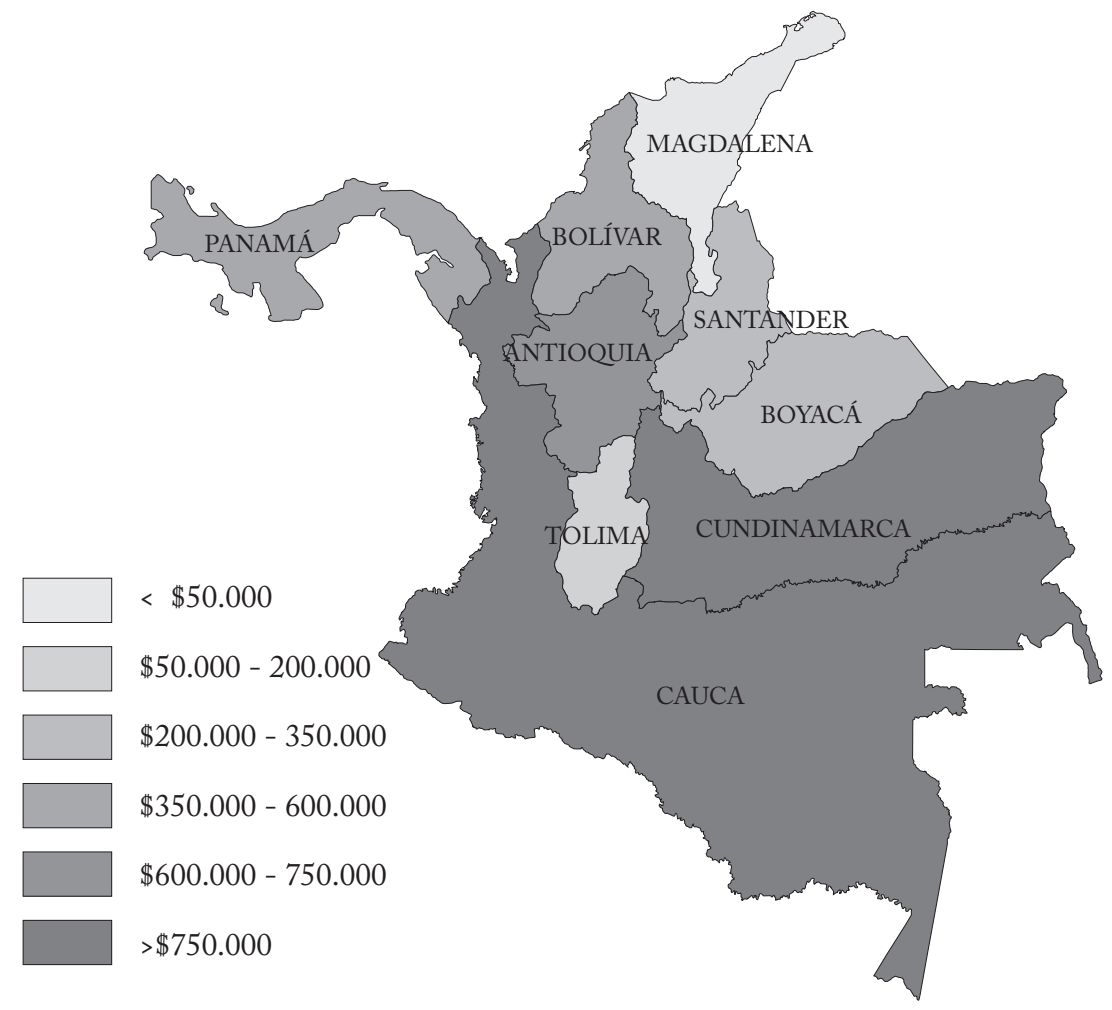

Fuente: Ajente General de Bienes Desamortizados, cuadro 3; cálculos de los autores.

El mayor valor se concentraba en Cundinamarca, sobre todo en Bogotá, con el 26,6\% del valor total redimido hasta 1873. Lo seguían los estados del Cauca y de Antioquia, donde se concentraba la minería del oro, la principal exportación del país desde la época colonial. El valor más bajo se registró en Magdalena, con el 0,4\% del total. Este estado era el más despoblado de los Estados Unidos de Colombia, y quizá el más pobre. En 1864 su población sólo era de 88.890 personas, el 3,3\% del total (Gómez, 1970, tabla 9).

\footnotetext{
${ }^{20}$ Ajencia General de Bienes Desamortizados, Bogotá, Imprenta de Gaitán, 1869, p. VIII.
} 
La redención de censos llegó al máximo en 1865, cuando se pagaron $\$ 1.552 .854$. Fue alta hasta 1868 y luego declinó rápidamente, de modo que en el cuatrienio 1865-1868 se hicieron los principales avances (cuadro 7).

Cuadro 7

Redención anual y acumulada de censos y deudas, 1862-1873 (Pesos corrientes)

\begin{tabular}{lrr}
\hline Año & Redención anual & Acumulado \\
\hline 1862 & 4.968 & 4.968 \\
1863 & 155.318 & 160.286 \\
1864 & 286.891 & 447.178 \\
1865 & 1.552 .854 & 2.000 .031 \\
1866 & 737.842 & 2.737 .873 \\
1867 & 698.719 & 3.436 .592 \\
1868 & 614.043 & 4.050 .635 \\
1869 & 121.433 & 4.172 .068 \\
1870 & n.d. & 4.172 .068 \\
1871 & n.d. & 4.172 .068 \\
1872 & n.d. & 4.172 .068 \\
1873 & 127.413 & 4.299 .481 \\
N.d. & 11.336 & 4.310 .817 \\
Total & & 4.310 .817 \\
\hline
\end{tabular}

n.d.: no disponible.

Fuente: Ajente General de Bienes Desamortizados, varios años; cálculos de los autores.

Cuadro 8

Valor per cápita de los censos desamortizados, por estado, 1862-1873

(Pesos corrientes)

\begin{tabular}{ll}
\hline Estados & Valor \\
\hline Cundinamarca & 2,80 \\
Panamá & 1,89 \\
Cauca & 1,83 \\
Antioquia & 1,73 \\
Bolívar & 1,73 \\
Tolima & 0,86 \\
Boyacá & 0,51 \\
Santander & 0,49 \\
Magdalena & 0,21 \\
\hline
\end{tabular}

Fuente: Ajente General de Bienes Desamortizados, varios años; cálculos de los autores.

En términos per cápita, las redenciones de censos fueron mayores en Cundinamarca y en Panamá (cuadro 8). En ambos casos con una gran participación de bienes urbanos, como casas, lotes y tiendas. Magdalena ocupó el último lugar, lo que muestra claramente su estancamiento en esa época.

Al tiempo de la redención, la abrumadora mayoría de los préstamos a censo, el 86,8\%, estaban colocados a un interés del $5 \%$ anual, prác- 
tica heredada del siglo XVIII, y sólo el 0,5\% pagaba tasas superiores al 6\% (cuadro 9).

Mapa 4

Valor de los censos y deudas redimidos per cápita, 1862-1873

(Pesos corrientes)

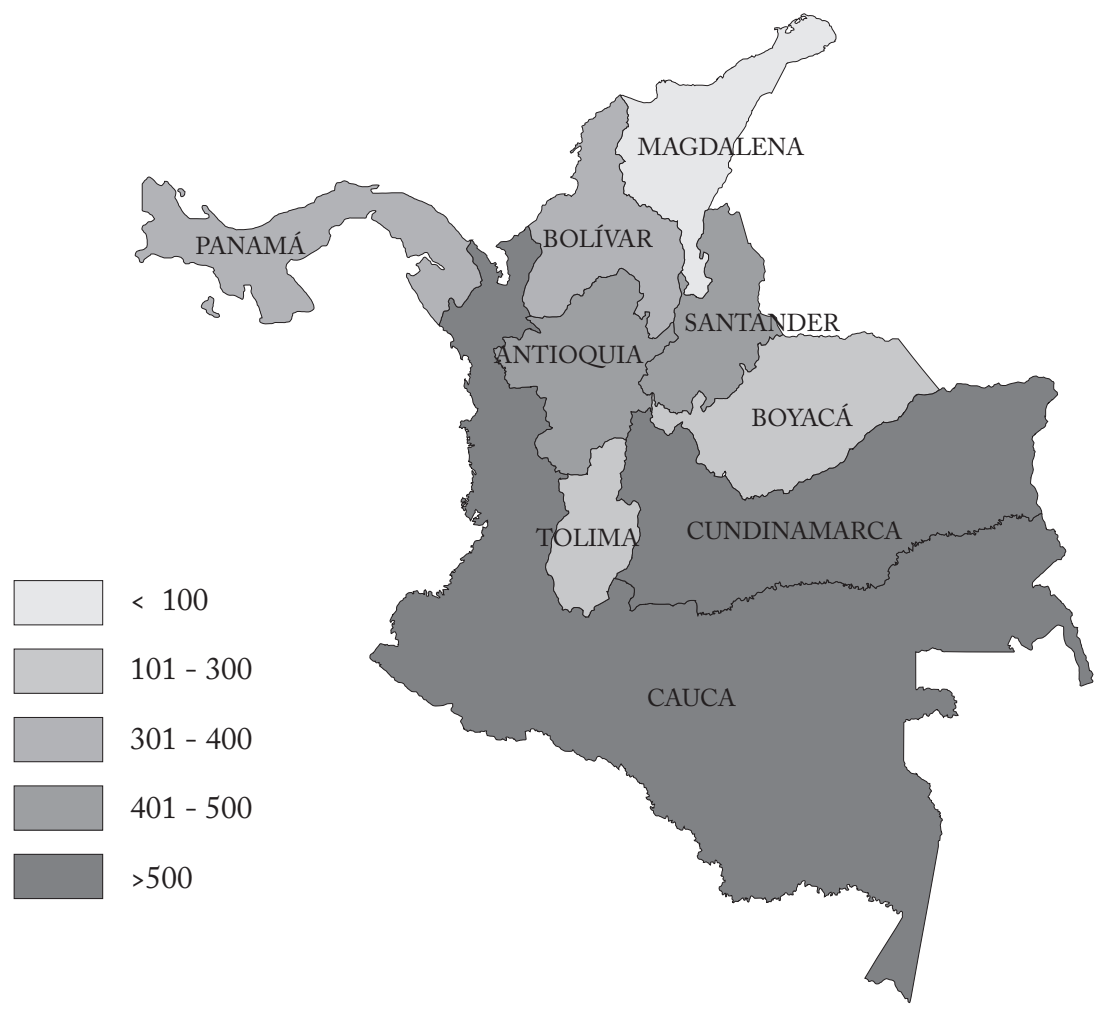

Fuente: Ajente General de Bienes Desamortizados, varios años; cálculos de los autores.

Habrá qué ver si uno de los obstáculos al desarrollo del sistema bancario fueron estos intereses, fijados más por la costumbre que por los vaivenes del mercado de crédito.

Los bienes sobre los que recaían los préstamos a censo eran muy variados: haciendas, minas, casas, terrenos con árboles, islas, molinos, edificios, salinas, solares, tiendas, pajas de agua y quintas. Por su valor, los más comunes eran las casas, las haciendas y los terrenos (cuadro 10). Esto cambiaba de acuerdo con los estados y el tipo de economía. Por ejemplo, en el Cauca las haciendas eran los bienes que tenían mayor valor, mientras que en Panamá lo eran las casas. 


\section{Cuadro 9}

Intereses anuales que pagaban los censos redimidos, 1862-1873 (Porcentaje y pesos corrientes)

\begin{tabular}{lrr}
\hline Intereses & $\begin{array}{c}\text { Número } \\
\text { de bienes }\end{array}$ & Capital \\
\hline 1 & 4 & 2.960 \\
1,5 & 4 & 4.000 \\
2 & 2 & 60 \\
3 & 655 & 472.104 \\
4 & 12 & 15.646 \\
5 & 5.274 & 3.739 .994 \\
6 & 182 & 56.306 \\
6,5 & 1 & 74 \\
7 & 2 & 2.060 \\
8 & 24 & 6.034 \\
10 & 19 & 8.832 \\
11 & 1 & 160 \\
12 & 12 & 2.226 \\
15 & 3 & 360 \\
Total & 6.195 & 4.310 .817 \\
\hline
\end{tabular}

Fuente: Ajente General de Bienes Desamortizados, varios años; cálculos de los autores.

Cuadro 10

Valor y número de los censos desamortizados por tipo de bien y estado, 1862-1873

\begin{tabular}{|c|c|c|c|c|c|c|c|c|c|c|}
\hline & \multicolumn{2}{|c|}{ Antioquia } & \multicolumn{2}{|c|}{ Bolívar } & \multicolumn{2}{|c|}{ Boyacá } & \multicolumn{2}{|c|}{ Cauca } & \multicolumn{2}{|c|}{ Cundinamarca } \\
\hline & No. & Valor & No. & Valor & No. & Valor & No. & Valor & No. & Valor \\
\hline \multicolumn{11}{|l|}{ Almacén } \\
\hline \multicolumn{11}{|l|}{ Árboles } \\
\hline \multicolumn{11}{|l|}{ Árboles y hacienda } \\
\hline \multicolumn{11}{|l|}{ Árboles y terreno } \\
\hline \multicolumn{11}{|l|}{ Árb., ganado y casa } \\
\hline \multicolumn{11}{|l|}{$\begin{array}{l}\text { Árb., terreno, } \\
\text { potreros, ganado }\end{array}$} \\
\hline \multicolumn{11}{|l|}{ Bodega } \\
\hline Casa & 200 & 69.874 & 302 & 269.736 & 29 & 12.926 & 295 & 210.778 & 283 & 316.604 \\
\hline Casa y almacén & & & 2 & 3.528 & & & 1 & 26 & 1 & 2.759 \\
\hline \multicolumn{11}{|l|}{ Casa y bodega } \\
\hline Casa y ganado & & & 1 & 945 & & & & & & \\
\hline Casa y hacienda & & & & & & & 1 & 800 & & \\
\hline Casa y paja de agua & 1 & 240 & & & & & & & & \\
\hline \multicolumn{11}{|l|}{ Casa y pesos } \\
\hline Casa y solar & 195 & 56.556 & 14 & 6.424 & 6 & 912 & 12 & 7.439 & 11 & 4.763 \\
\hline Casa y tienda & & & 11 & 27.348 & & & & & 11 & 10.653 \\
\hline \multicolumn{11}{|l|}{ Casa, solar y árboles } \\
\hline \multicolumn{8}{|l|}{ hacienda } & 1.600 & & \\
\hline \multicolumn{11}{|l|}{ Casa, solar y molino } \\
\hline $\begin{array}{l}\text { Casa, solar y paja } \\
\text { de agua }\end{array}$ & 1 & 640 & & & & & & & & \\
\hline Casa, solar y terreno & 4 & 1.120 & & & & & & & & \\
\hline Casa, solar y tienda & 1 & 800 & & & & & & & 1 & 320 \\
\hline \multicolumn{11}{|l|}{ Cofradía } \\
\hline Cuarto & & & 1 & 918 & & & & & & \\
\hline Diversos bienes & & & 5 & 3.496 & & & 1 & 1.600 & 3 & 308 \\
\hline $\begin{array}{l}\text { Diversos bienes y } \\
\text { ganado }\end{array}$ & & & 1 & 1.136 & & & & & & \\
\hline Edificio & & & 1 & 240 & & & & & 1 & 3216 \\
\hline Finca & 5 & 2.096 & & & 1 & 700 & 19 & 10.901 & 11 & 20.941 \\
\hline Finca y mina & & & & & & & 1 & 5.333 & & \\
\hline
\end{tabular}




\begin{tabular}{|c|c|c|c|c|c|c|c|c|c|c|c|c|}
\hline Ganado & & & 6 & 4.517 & & & & & & & & \\
\hline Hacienda & 13 & 7.900 & 45 & 37.729 & 40 & 78.623 & 429 & 375.902 & 192 & 395.257 & & \\
\hline Hacienda y finca & & & & & & & 1 & 476 & & & & \\
\hline \multicolumn{13}{|l|}{ Hacienda y ganado } \\
\hline Hacienda y potrero & & & & & 1 & 496 & 1 & 720 & 1 & 3200 & & \\
\hline Hacienda y solar & & & & & & & 5 & 187 & & & & \\
\hline Hacienda y terreno & & & & & & & 1 & 589 & 2 & 2.240 & & \\
\hline Isla & & & 3 & 2.000 & & & & & & & & \\
\hline Mina & & & & & & & 36 & 62.963 & & & & \\
\hline Molino & & & & & 5 & 1.700 & & & 3 & 5.008 & & \\
\hline Montaña & 23 & 8.170 & & & & & & & & & & \\
\hline Paja de agua & 5 & 288 & & & & & & & & & & \\
\hline Potrero & 3 & 6.216 & & & 9 & 7.916 & 24 & 11.089 & 24 & 35.460 & & \\
\hline \multicolumn{13}{|l|}{ Potrero y montaña } \\
\hline Quinta & 2 & 1.984 & & & 1 & 160 & 7 & 2.860 & 27 & 25.140 & & \\
\hline \multicolumn{13}{|l|}{ Rentas } \\
\hline Salina & & & & & & & 3 & 2.800 & & & & \\
\hline Solar & 18 & 2.749 & 31 & 7.149 & 1 & 619 & 4 & 820 & 6 & 1.856 & & \\
\hline Solar y terreno & 3 & 743 & & & 1 & 184 & & & 1 & 2.400 & & \\
\hline Solar y tienda & & & & & & & & & 1 & 1.288 & & \\
\hline Terreno & 1.267 & 403.686 & 46 & 31.811 & 173 & 122.258 & 123 & 57.291 & 210 & 288.079 & & \\
\hline Terreno y casa & 154 & 56.223 & 2 & 2.084 & 4 & 1.716 & 9 & 6.116 & 2 & 1.760 & & \\
\hline Terreno y ganado & 1 & 474 & 6 & 7.761 & & & 1 & 240 & & & & \\
\hline Terreno y molino & & & & & 2 & 680 & 2 & 2.520 & 4 & 5.703 & & \\
\hline \multicolumn{13}{|l|}{ Terreno y tienda } \\
\hline \multicolumn{13}{|l|}{$\begin{array}{l}\text { Terreno, casa y } \\
\text { ganado }\end{array}$} \\
\hline \multicolumn{13}{|l|}{$\begin{array}{l}\text { Terreno, casa, } \\
\text { ganado, esclava, } \\
\text { sementera }\end{array}$} \\
\hline Tienda & & & 1 & 1.216 & 5 & 1.008 & 12 & 6.642 & 17 & 28.430 & & \\
\hline Tienda y almacén & & & & & & & & & 1 & 4.000 & & \\
\hline \multicolumn{13}{|l|}{ Tienda y ganado } \\
\hline N.d. & 4 & 312 & & & & & 6 & 7.438 & 6 & 8.728 & & \\
\hline \multirow[t]{3}{*}{ Total } & 1900 & 620.072 & 478 & 408.038 & 278 & 229.897 & 995 & 777.130 & 819 & 1.108 .112 & & \\
\hline & \multicolumn{2}{|c|}{ Magdalena } & \multicolumn{2}{|c|}{ Panamá } & \multicolumn{2}{|c|}{ Santander } & & ima & & N.D. & & Total \\
\hline & No. & Valor & No. & Valor & No. & Valor & No. & Valor & No. & Valor & No. & Valor \\
\hline Almacén & & & & & & & & & 1 & 1.600 & 1 & 1.600 \\
\hline Árboles & & & & & 1 & 400 & 5 & 770 & & & 6 & 1.170 \\
\hline Árboles y hacienda & & & & & & & 1 & 1.040 & & & 1 & 1040 \\
\hline Árboles y terreno & & & & & & & 3 & 1.586 & & & 3 & 1.586 \\
\hline Árboles, ganado & & & & & & & 1 & 320 & & & 1 & 320 \\
\hline y casa & & & & & & & & & & & & \\
\hline $\begin{array}{l}\text { Árboles, terreno, } \\
\text { potreros, ganado }\end{array}$ & & & & & & & 1 & 977 & & & 1 & 977 \\
\hline Bodega & & & 7 & 3.412 & & & & & & & 7 & 3.412 \\
\hline Casa & 20 & 14.094 & 170 & 168.722 & 115 & 32.865 & 20 & 8.151 & 107 & 138.499 & 1.541 & 1.242 .249 \\
\hline Casa y almacén & & & & & & & & & & & 4 & 6312 \\
\hline Casa y bodega & & & 3 & 4.762 & & & & & & & 3 & 4.762 \\
\hline Casa y ganado & & & & & & & & & & & 1 & 945 \\
\hline Casa y hacienda & & & 8 & 6.179 & 3 & 3200 & & & & & 12 & 10.179 \\
\hline Casa y paja de agua & & & & & & & & & & & 1 & 240 \\
\hline Casa y pesos & & & & & & & 1 & 80 & & & 1 & 80 \\
\hline Casa y solar & & & 8 & 3.557 & 6 & 1.440 & 2 & 1.080 & 2 & 600 & 256 & 82.771 \\
\hline Casa y tienda & & & & & & & 2 & 4.000 & 5 & 20.840 & 29 & 62.841 \\
\hline Casa, solar y árboles & & & & & 1 & 400 & & & & & 1 & 400 \\
\hline $\begin{array}{l}\text { Casa, solar y } \\
\text { hacienda }\end{array}$ & & & & & & & & & & & 1 & 1600 \\
\hline Casa, solar y molino & & & & & 2 & 480 & & & & & 2 & 480 \\
\hline $\begin{array}{l}\text { Casa, solar y paja } \\
\text { de agua }\end{array}$ & & & & & & & & & & & 1 & 640 \\
\hline Casa, solar y terreno & & & & & 1 & 240 & & & & & 5 & 1.360 \\
\hline Casa, solar y tienda & & & & & & & & & 1 & 1.040 & 3 & 2.160 \\
\hline Cofradía & & & & & 1 & 160 & & & & & 1 & 160 \\
\hline Cuarto & & & & & & & & & & & 1 & 918 \\
\hline Diversos bienes & 1 & 81 & & & & & 8 & 1.813 & 24 & 15.155 & 42 & 22.453 \\
\hline $\begin{array}{l}\text { Diversos bienes y } \\
\text { ganado }\end{array}$ & & & & & & & & & & & 1 & 1.136 \\
\hline Edificio & & & & & & & & & & & 2 & 3.456 \\
\hline Finca & & & 2 & 412 & 1 & 1.040 & & & 5 & 1.955 & 44 & 38.045 \\
\hline
\end{tabular}




\begin{tabular}{|c|c|c|c|c|c|c|c|c|c|c|c|c|}
\hline Finca y mina & & & & & & & & & & & 1 & 5.333 \\
\hline Ganado & 2 & 630 & 53 & 42.880 & 1 & 80 & 2 & 280 & 15 & 11.236 & 79 & 59.624 \\
\hline Hacienda & 1 & 560 & 60 & 78.693 & 85 & 57.565 & 50 & 82.997 & 7 & 9.972 & 922 & 1.124 .999 \\
\hline Hacienda y finca & & & & & & & & & & & 1 & 476 \\
\hline Hacienda y ganado & & & 8 & 10.508 & & & & & 1 & 2.761 & 9 & 13.268 \\
\hline Hacienda y potrero & & & & & & & & & & & 3 & 4.416 \\
\hline Hacienda y solar & & & 8 & 7.091 & & & & & & & 13 & 7.278 \\
\hline Hacienda y terreno & & & & & & & & & & & 3 & 2.829 \\
\hline Isla & & & 2 & 666 & & & & & & & 5 & 2.666 \\
\hline Mina & & & & & & & & & & & 36 & 62.963 \\
\hline Molino & & & & & & & & & & & 8 & 6.708 \\
\hline Montaña & & & & & & & & & & & 23 & 8.170 \\
\hline Paja de agua & & & & & & & & & 1 & 48 & 6 & 336 \\
\hline Potrero & & & 2 & 1.030 & 6 & 2.748 & 8 & 3.152 & 2 & 3.010 & 78 & 70.621 \\
\hline Potrero y montaña & & & & & & & 1 & 128 & & & 1 & 128 \\
\hline Quinta & & & & & & & 1 & 832 & 3 & 4.828 & 41 & 35.804 \\
\hline Rentas & & & & & & & 1 & 240 & & & 1 & 240 \\
\hline Salina & & & & & & & & & & & 3 & 2.800 \\
\hline Solar & & & 54 & 45.244 & 11 & 1.389 & 1 & 80 & 4 & 2.010 & 130 & 61.916 \\
\hline Solar y terreno & & & & & & & & & & & 5 & 3.327 \\
\hline Solar y tienda & & & & & & & & & 1 & 1.701 & 2 & 2.989 \\
\hline Terreno & 5 & 2.300 & 41 & 12.817 & 289 & 93.398 & 133 & 71.712 & 15 & 22.790 & 2.302 & 1.046 .141 \\
\hline Terreno y casa & & & 2 & 584 & 10 & 3.864 & 1 & 880 & & & 184 & 73.227 \\
\hline Terreno y ganado & & & & & & & 7 & 1.296 & & & 15 & 9.771 \\
\hline Terreno y molino & & & & & 2 & 512 & & & & & 10 & 9.415 \\
\hline Terreno y tienda & & & & & 1 & 580 & & & & & 1 & 580 \\
\hline Terr., casa y ganado & & & & & & & 1 & 74 & & & 1 & 74 \\
\hline $\begin{array}{l}\text { Terr., casa, ganado, } \\
\text { esclava, sementera }\end{array}$ & & & & & 3 & 876 & & & & & 3 & 876 \\
\hline Tienda & & & & & 2 & 165 & 2 & 1.880 & 6 & 5.207 & 45 & 44.548 \\
\hline Tienda y almacén & & & & & & & & & & & 1 & 4.000 \\
\hline Tienda y ganado & & & & & & & & & 1 & 1.600 & 1 & 1.600 \\
\hline N.d. & & & 1 & 93 & 2 & 386 & 2 & 1.108 & 66 & 17.668 & 87 & 35.732 \\
\hline Total & 29 & 17.666 & 429 & 386.650 & 543 & 201.787 & 254 & 184.477 & 267 & 262.320 & 5.992 & 4.196 .149 \\
\hline
\end{tabular}

n.d.: no disponible.

Fuente: Ajente General de Bienes Desarmortizados, varios años; cálculos de los autores.

\section{¿FUE IMPORTANTE LA DESAMORTIZACIÓN DESDE EL PUNTO DE VISTA ECONÓMICO?}

\section{IMPORTANCIA DE LA DESAMORTIZACIÓN EN LA HISTORIOGRAFÍA COLOMBIANA}

La historiografía colombiana no ha investigado ni examinado adecuadamente la desamortización. La percepción de su escasa importancia económica ha contribuido a que el tema sea poco estudiado y se repitan lugares comunes cuyo origen a menudo se remonta a los juicios desviados de quienes se opusieron a esa reforma en el siglo XIX. Los fundadores de los estudios de historia económica de Colombia también contribuyeron a difundir la idea de la poca relevancia del proceso desamortizador, a pesar de sus enfoques ideológicamente contrapuestos: Luis Eduardo Nieto Arteta era marxista y Luis Ospina Vásquez exponente de las ideas conservadoras. En su libro clásico Economía y cultura en la historia de Colombia, publicado en 1941, Nieto Arteta ignoró la desamortización. Tal vez tomó esta vía fácil 
porque algunas fuentes, como las Memorias de Hacienda, no contienen prácticamente nada sobre el tema, que se trataba en las Memorias del Tesoro y en los Informes anuales de la Ajencia General de Bienes Desamortizados. En su bibliografía no menciona una sola Memoria del Tesoro ni los Informe del Ajente General de Bienes Desamortizados. Lo mismo ocurrió con Luis Ospina Vásquez, usualmente muy bien documentado. Sin aludir a información empírica señaló:

\begin{abstract}
La desamortización de bienes eclesiásticos y otros (de universidades y otras instituciones y entidades), que tuvo un éxito moderado desde el punto de vista fiscal, cambió ligeramente la forma del latifundismo en los pocos sitios donde los bienes de manos muertas representaban una extensión considerable, pero en general, aunque alguien la calificó recientemente de "medida salvadora de la industria agropecuaria", fue de importancia secundaria por los aspectos económicos y sociales (Ospina, 1974, 289).
\end{abstract}

Es notoria la impronta de esos fundadores sobre la percepción de dicho proceso en historiadores colombianos posteriores a ellos, pues desde los marxistas hasta los conservadores minimizan su importancia, con argumentos diferentes. Casi todos se refieren al tema sin haber estudiado las fuentes primarias disponibles, como los fondos de desamortización del Archivo General de la Nación, las Memorias del Tesoro y los Informes de la Ajencia General de Bienes Desamortiza$d^{2} s^{21}$. También coinciden en que la mayoría de sus argumentos acerca de los aspectos económicos de la desamortización no tienen sólidos fundamentos empíricos.

E1 texto Introducción a la historia económica de Colombia, de Álvaro Tirado Mejía, quizá el más vendido en esta materia hasta la fecha, afirma que la desamortización empeoró la situación de la propiedad de la tierra, ya de por sí muy concentrada, pues:

Como triunfaron los intereses de los comerciantes y de los generales liberales, la propiedad no se dividió y antes por el contrario el latifundio se afianzó trastocándose de religioso en seglar (Tirado, 1988, 175).

En otro texto introductorio de amplia circulación, Historia económica de Colombia, editado por José Antonio Ocampo, en el capítulo correspondiente a 1850-1899, Jorge Orlando Melo se refiere brevemente al intento de redimir los censos de José Hilario López, pero no analiza

\footnotetext{
${ }^{21}$ Dos excepciones, referidas al ámbito de un Estado o ciudad, son Fernando Díaz sobre la desamortización en Boyacá, y Sergio Uribe Arboleda, sobre Bogotá. E1 primero utilizó numerosa fuentes primarias locales, como los Protocolos de Tunja, los informes del Secretario de Hacienda de Boyacá y los informes del presidente del Estado a la Asamblea. También usó algunos informes de la Ajencia General de Bienes Desamortizados. Por su parte, Sergio Uribe utilizó la información existente en el Archivo General de la Nación, los Fondos de Desamortización y el Ministerio del Tesoro; ver Díaz (1977) y Uribe (1976).
} 
la desamortización. En esta materia, Melo continúa la tradición de ignorarla $(1987,149-153)$.

Otro historiador conocido que minimiza la importancia económica de la desamortización en Colombia es Malcolm Deas. En su opinión:

Esta confiscación y sus resultados fueron menores de lo que se había esperado por las siguientes razones: la Iglesia resultó ser menos rica de lo que sus entusiastas enemigos habían supuesto; el gobierno estaba muy necesitado [...] y no podía efectuar las ventas de la manera paciente y cuidadosa requerida para asegurar los precios más altos (Deas, 1993, 91).

¿Por qué la historiografía colombiana ha dado tan poco valor a los efectos económicos de la desamortización? Pensamos que buena parte de los autores retomaron, sin crítica, los juicios de los actores que expresaron con más beligerancia sus opiniones negativas sobre la desamortización, a saber, la alianza de los miembros del Partido Conservador y del ala del Partido Liberal que llegó a llamarse Independiente, que apoyó a Rafael Núñez. Muchos de esos críticos impulsaron la Regeneración, que desmontó algunas reformas de los liberales radicales y remplazó la Constitución de 1863 por la Constitución centralista de 1886. Buena parte de las opiniones de los conservadores y la posterior historiografía sobre la desamortización se ajustan a lo que Albert O. Hirschman llama "retórica de la intransigencia", el tipo de argumentos que suelen exponer los opositores de las "políticas progresistas" (Hirschman, 1991, 7) 22. De acuerdo con Hirschman, los tres tipos de argumentos contra las reformas progresistas son la perversidad, la futilidad y el riesgo. La tesis de la perversidad dice que el cambio puede empeorar las condiciones que se busca cambiar; la de la futilidad, que el efecto de la reforma será muy limitado o nulo; y la del riesgo, que el costo de las transformaciones es muy alto pues pone en peligro los logros anteriores (ibíd.).

En la obra de Juan Pablo Restrepo encontramos ejemplos de esas tres tesis en el contexto de la desamortización que realizaron los radicales ${ }^{23}$. En primer lugar, esgrime la perversidad, pues según su retórica argumental los campesinos se perjudicaron:

\footnotetext{
${ }^{22}$ Hirschman señala que estos argumentos no son exclusivos de los grupos "reaccionarios", pues también pueden ser esgrimidos por cualquier grupo que se oponga a nuevas políticas, aunque son típicos de los ataques conservadores a las reformas progresistas. Es importante señalar que ese autor, y aquí seguimos su práctica, no usa el término reaccionario en ningún sentido peyorativo. Ver Hirschman (1991, 7).

${ }^{23}$ Juan Pablo Restrepo (1840-1896) era conservador, antioqueño y hermano del obispo de Pasto, Manuel Canuto Restrepo. Terminó de escribir su obra en 1871.
} 
Las innumerables fincas que se decían muertas estaban dadas en arrendamiento a precios ínfimos, al alcance de la clase desvalida, es decir, de la masa social; hoy no pueden tomarlas sino las personas acomodadas, que no son muchas, y la gente pobre ha tenido que refugiarse en barracas formadas de escombros y desperdicios en donde agonizan y mueren en horroroso abandono centenares de individuos que podían ser útiles a la sociedad. Luego, si se quiso hacer el bien, se produjo un grave mal (Restrepo, 1885, 416) ${ }^{24}$.

También usa el argumento de la futilidad pues aunque una de las principales razones para la desamortización fue el pago de la deuda pública doméstica, dice que "La deuda no se pagó" (ibíd., 415)25. En cuanto al argumento del riesgo, dice que la reforma contribuyó a la inestabilidad y al enfrentamiento político donde no lo había:

E1 clero y las monjas no eran enemigos de la revolución. Esta había levantado como bandera "la soberanía de los Estados", y los que habían consagrado su vida a Dios nada tenían que ver con que los Estados fueran o no soberanos (ibíd., 416) ${ }^{26}$.

\section{ANÁlisis EMPírico de los ASPECTOS ECONÓMICOS DE LA DESAMORTIZACIÓN}

La evaluación que se ha hecho hasta hoy de la importancia económica de la desamortización por lo general se ha basado en la lógica de la "retórica de la reacción" o en juicios impresionistas y poco fundamentados en la evidencia empírica. Aquí presentamos una revisión sistemática de la dimensión económica de la desamortización para juzgar su importancia relativa, saber si fue un buen negocio para la Nación y discutir, con la evidencia fragmentaria disponible, algunas consecuencias de esa reforma. En uno de los trabajos más completos sobre los aspectos económicos de la desamortización, Fernando Díaz dice, para minimizar por contraste su incidencia en nuestro país:

Las riquezas de la Iglesia neogranadina no tenían la magnitud que algunos anticlericales imaginaron; por lo menos no se podían comparar por ejemplo, con las del clero mexicano (Díaz, 1984, 449).

Debemos señalar que nunca se menciona un cálculo previo de los promotores de la desamortización para sustentar que el valor real

${ }^{24}$ Dos historiadores económicos contemporáneos que suscribieron la tesis de la perversidad de la desamortización, por creer que ayudó a consolidar el latifundio y la concentración de la tierra, son Tirado $(1988,175)$ y McGreevey (1971, 117).

${ }^{25}$ Luis Ospina Vásquez y Malcolm Deas aceptan la tesis de la futilidad de la desamortización. El primero señala que fue "de importancia muy secundaria por los aspectos económicos y sociales", y el segundo argumenta que la Iglesia local no era muy rica, que una parte se recibió del pago en bonos y por ello llegó "poco dinero fresco", y el gobierno tuvo que compensar a la Iglesia por las expropiaciones.

${ }_{26}$ Ospina Vásquez y McGreevey parecen identificarse con este argumento del riesgo. 
resultó inferior. Esa aseveración es un simple recurso retórico pues si el valor final hubiese sido menor que el esperado eso no disminuiría su importancia relativa. Díaz no hizo la comparación con México, sólo la enuncia, sin dar cifras. Ahora bien, la estimación más alta del valor de las propiedades eclesiásticas mexicanas antes de la desamortización la hizo Jan Banzant, que lo calculó en unos $\$ 100.000 .000$ de la época $(1971,13)$. Ya señalamos que el valor de lo desamortizado en Colombia se acercó a $\$ 20.000 .000$. Para una comparación rigurosa hay que tener en cuenta que en esa época la población de México era más de tres veces la de Colombia y el PIB per cápita mexicano alrededor de dos veces el colombiano (ver apéndice 1). Por ello, la diferencia del valor de la reforma en estos dos países no es tan grande. El cuadro 11 compara los tamaños relativos de los bienes desamortizados en México y Colombia. En México equivalía al 23,0\% del PIB de 1860 y en Colombia al 16,1\%. Esas son magnitudes importantes. Por ejemplo, el ahorro social por la construcción de ferrocarriles en Colombia, México y Brasil (usando una elasticidad de la demanda de -0,5) fluctúa entre 2,3 y $4,1 \%, 14,9$ y $16,6 \%$ y $11,2 \%$, respectivamente (Ramírez, 2007, 416). Cabe destacar que el ahorro social por la construcción de los ferrocarriles en México es el más alto estimado a la fecha para cualquier país. Por tanto, si los bienes desamortizados en Colombia representaban un $16,1 \%$ del PIB, esa fue una de las principales reformas económicas que se hicieron en el siglo XIX en nuestro país. Además, hay que tener en cuenta que nuestro cálculo sesga el resultado hacia abajo, pues adoptamos supuestos que castigan el valor de los bienes para asegurar que sea un valor mínimo.

Cuadro 11

Tamaño económico relativo de la desamortización en Colombia y México (Pesos corrientes)

\begin{tabular}{lcc}
\hline Concepto & Colombia & México \\
\hline Valor de los bienes desamortizados & 20.000 .000 & 100.000 .000 \\
Bienes desamortizados (\% del PIB de 1860) & Valor mínimo 16,1 & 23,0 \\
$\begin{array}{l}\text { Número de veces que los bienes desamortizados } \\
\text { superan al valor de las rentas del gobierno federal }\end{array}$ & 13,3 & 6,0 \\
$\begin{array}{l}\text { (Colombia) y los gastos del gobierno federal } \\
\text { (México) }\end{array}$ & & \\
$\begin{array}{l}\text { Valor en pesos de los bienes desamortizados per } \\
\text { cápita usando la población de México en 1862 y }\end{array}$ & 4,0 & 11,9 \\
la de Colombia en 1864 & & \\
\hline
\end{tabular}

Fuente: apéndice 1.

El cuadro 11 también muestra que el valor de la desamortización en Colombia, en relación con el presupuesto de ingresos del gobierno de 
la Unión en esa época, era alto, y mayor que en México. En cuanto al valor per cápita, México sale mejor librado porque era más rico.

Los críticos de la desamortización a menudo señalaron que había concentrado la propiedad de la tierra. Cabe aclarar que aunque no creó una sociedad rural o urbana de pequeños propietarios -y ese no era su objetivo principal- sí desconcentró la propiedad rural y urbana. En efecto, al pasar de unos pocos propietarios, concentrados en obras pías controladas por la Iglesia Católica, a una masa mayor de propietarios, es obvio que la concentración se redujo por puras razones aritméticas. No tenemos información detallada de los remates de finca raíz que permita evaluar este cambio en forma detallada. Pero consta que se hizo un esfuerzo por fraccionar las propiedades de mayor tamaño para vender unidades más pequeñas que permitieran ampliar el acceso a ellas. En una circular del 14 de julio de 1862, Rafael Núñez, en ese momento Secretario del Tesoro, señaló que con la desamortización no sólo se pretendía poner en circulación "una masa considerable de valores inertes", sino que también:

se trata de resolver con la desamortización, hasta donde es posible, el arduo e inmenso problema de la distribución inequitativa de la propiedad sin perjuicios de ningún derecho individual anterior (Liévano, 1968, 52-53).

Cuadro 12

Número de personas que redimieron censos y valor del capital de los censos, 1862-1873

\begin{tabular}{lccrc}
\hline $\begin{array}{l}\text { Censos por } \\
\text { persona }\end{array}$ & $\begin{array}{c}\text { Número de } \\
\text { personas }\end{array}$ & $\begin{array}{c}\text { Porcentaje } \\
\text { de personas }\end{array}$ & Valor & $\begin{array}{c}\text { Porcentaje } \\
\text { del valor }\end{array}$ \\
\hline 16 & 1 & 0,02 & 5.902 & 0,14 \\
15 & 2 & 0,05 & 28.781 & 0,67 \\
13 & 2 & 0,05 & 22.550 & 0,52 \\
12 & 2 & 0,05 & 21.916 & 0,51 \\
11 & 3 & 0,07 & 39.000 & 0,91 \\
10 & 5 & 0,12 & 49.204 & 1,14 \\
9 & 5 & 0,12 & 47.546 & 1,11 \\
8 & 11 & 0,27 & 87.245 & 2,03 \\
7 & 15 & 0,27 & 83.767 & 1,95 \\
6 & 37 & 0,92 & 197.846 & 4,60 \\
5 & 57 & 1,42 & 224.198 & 5,21 \\
4 & 92 & 2,29 & 312.526 & 7,26 \\
3 & 224 & 5,57 & 457.160 & 10,63 \\
2 & 660 & 16,40 & 873.093 & 20,29 \\
1 & 2.908 & 72,27 & 1.851 .416 & 43,03 \\
Total & 4.024 & 100,00 & 4.302 .151 & 100,00 \\
\hline
\end{tabular}

Fuente: Ajente General de Bienes Desamortizados, varios años; cálculos de los autores. 
Con ese fin se dieron plazos para cancelar las propiedades rematadas, algunas propiedades se dividieron en lotes y se suprimieron las fianzas personales (ibíd., 53). Un ejemplo de la subdivisión de una propiedad raíz para su remate fue el de la hacienda "Las Monjas", en Boyacá, quizá la de mayor valor entre las propiedades rurales. Esa hacienda se avaluó en $\$ 297.986$ y se dividió en ocho partes para su venta (Pardo, 1972, 261).

Gráfica 1

Curva de Lorenz para la distribución del valor de los censos redimidos, 1862-1873

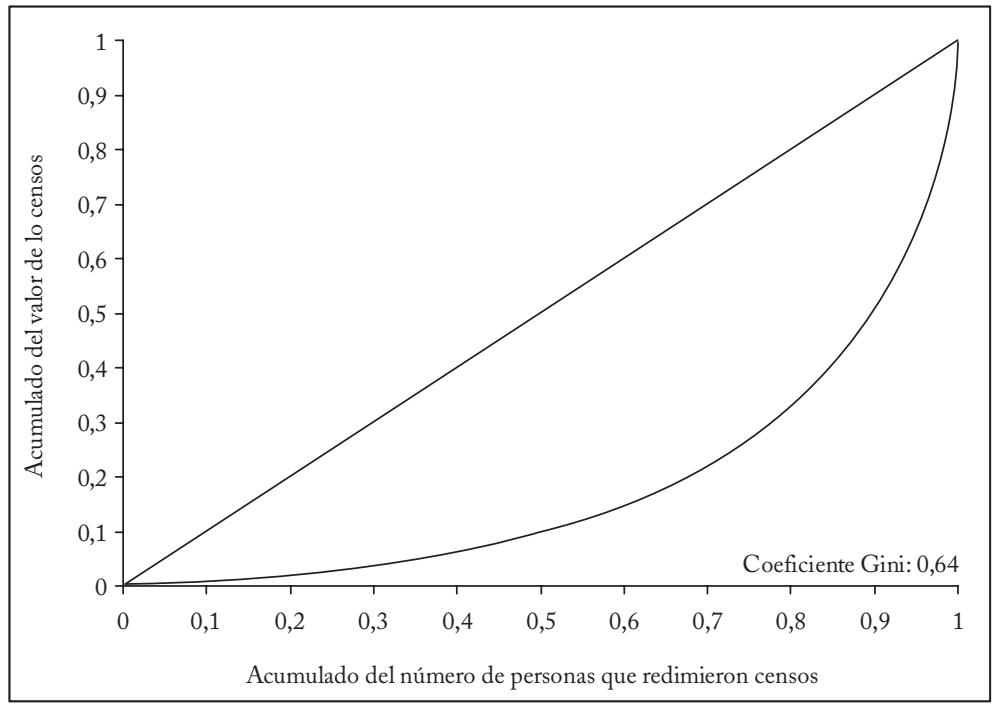

Fuente: cuadro 12; cálculos de los autores.

En cambio, tenemos información detallada de la redención de censos y deudas que permite calcular el grado de concentración. En efecto, respecto de los $\$ 4.302 .151$ ingresados por censos redimidos, se concluye que un total de 4.024 personas estuvieron vinculadas con el proceso. La mayoría de ellas, un 43,03\%, redimieron un censo, y sólo 15 personas redimieron diez o más censos (cuadro 12). La gráfica 1 muestra la curva de Lorenz de los censos redimidos entre 1862 y 1873. E1 coeficiente de Gini de esa distribución es de 0,64, menor que el de la distribución de la tierra en Colombia en la actualidad, de 0,85 (Banco Mundial, 2004).

El examen de las 20 personas que redimieron más de nueve censos entre 1862 y 1873 muestra que los valores no son muy elevados. 
José María Valle Maya redimió el mayor número, 16 censos, y sólo pagó \$5.902 (cuadro 13). Quien más pagó, Agustín Arias, canceló \$19.122. Es decir, en materia de censos no hubo gran concentración. En el apéndice 2 de Jaramillo y Meisel $(2008,54)$ se relacionan los 25 censos de mayor valor que se redimieron en ese período. Su valor fluctúa entre $\$ 16.000$ y $\$ 8.000$. En total suman $\$ 250.905$, es decir, el $5,8 \%$ del valor total redimido.

En el apéndice 3 de Jaramillo y Meisel $(2008,55)$ se presenta un resumen de los censos liberados entre 1862 y 1873, para las 20 personas que redimieron los mayores valores. La mayoría corresponde a haciendas, aunque también figuran casas y tiendas. Por ejemplo, Eusebio J. Ponce redimió el 29 de junio de 1865 un préstamo acensuado a favor del Convento de Santo Domingo, sobre dos casas y diez tiendas en la Carrera del Norte, cuyo valor era de $\$ 12.800$.

Cuadro 13

Veinte personas con el mayor número de censos redimidos, 1862-1873 (Pesos corrientes)

\begin{tabular}{|c|c|c|c|}
\hline Apellido & Nombres & $\begin{array}{c}\text { Total de bienes } \\
\text { raíces } \\
\text { redimidos }\end{array}$ & $\begin{array}{c}\text { Valor del } \\
\text { capital } \\
\text { de los censos } \\
\text { redimidos }\end{array}$ \\
\hline Valle Maya & José María & 16 & 5.902 \\
\hline Macía & Pedro & 15 & 9.659 \\
\hline Arias & Agustín & 15 & 19.122 \\
\hline Bucheli & Blas María & 13 & 7.142 \\
\hline Vélez & Agustín & 13 & 15.408 \\
\hline Gutiérrez de Lara & Jorge & 12 & 8.670 \\
\hline Nelson & Guillermo & 12 & 13.246 \\
\hline Arboleda & Sergio & 11 & 2.290 \\
\hline Dávila Novoa & Pedro & 11 & 18.120 \\
\hline Mosquera & Sofía & 11 & 18.590 \\
\hline Amador & Manuel & 10 & 6.631 \\
\hline De Sabla \& Cia. & n.d. & 10 & 7.073 \\
\hline Solano Durán & Joaquín & 10 & 9.274 \\
\hline Hurtado & Manuel J. & 10 & 10.128 \\
\hline Mosquera & Manuel María, Pedro María y José & 10 & 16.098 \\
\hline De la Villota & María & 9 & 3.824 \\
\hline Córdoba & Paulino & 9 & 4.422 \\
\hline Cabal de Hoyos & José María & 9 & 5.799 \\
\hline Arce & José Manuel & 9 & 11.797 \\
\hline Hernández & José María & 9 & 21.705 \\
\hline Total & & 224 & 214.900 \\
\hline
\end{tabular}

Fuente: Ajente General de Bienes Desamortizados, varios años; cálculos de los autores.

\footnotetext{
${ }^{27}$ José María Maya era liberal y durante algún tiempo fue agente de manos muertas en Antioquia.
} 


\title{
AlgunOS EFECTOS ECONÓMICOS POSITIVOS DE LA DESAMORTIZACIÓN
}

La desamortización tuvo numerosos efectos económicos positivos. Se dio mayor seguridad jurídica a la propiedad raíz urbana y rural. Un grave problema de los préstamos a censo era que no había transparencia acerca de cuántos gravámenes recaían sobre una propiedad y por qué valor, pues podían estar ocultos o sus documentos de soporte podían haber desaparecido. Ello acarreaba un riesgo para el comprador de una propiedad raíz. Sobre esto dijo Salvador Camacho Roldán:

\begin{abstract}
Nadie, al comprar una finca, puede estar seguro de que no tenga gravámenes ocultos. Nadie puede saber si los réditos están puntualmente pagados en los treinta años anteriores, cuyo lapso es necesario para prescribir el canon anual de los gravámenes. La pérdida del archivo de una oficina de hipotecas basta para establecer confusión en todas las propiedades. Un acto de mala fe, o tan solo de error por parte de un administrador, puede reducir a la miseria a una familia (Camacho, 1976, 55-56).
\end{abstract}

La desamortización también dio mayor movilidad a la tierra. Muchas propiedades controladas por la Iglesia no eran enajenables. Además, las posesiones sobre las que recaía un censo eran más difíciles de vender, ya que no se podía transferir una parte sin redimir antes la totalidad del censo (ibíd., 56). Otro efecto importante fue que eliminó el principal obstáculo para el desarrollo de los bancos comerciales, el sistema inveterado de crédito basado en los censos, que eran de largo plazo y poco flexibles. En efecto, en 1861 no había un solo banco comercial en el país. Veinte años después, en 1881, había 42 bancos particulares (Hyland, 1982, 376). Este resultado fue fruto de la eliminación de los préstamos a censo que otorgaban las entidades religiosas o eclesiásticas y de la promulgación de la ley de bancos en 1865, que dio libertad a esas instituciones e incluso la posibilidad de emitir billetes convertibles en oro. E1 Informe del Ajente General de Bienes Desamortizados de 1875 al Secretario del Tesoro aludía a la creación de bancos hipotecarios y a la necesidad

de tener bases seguras para acometer la de la formación de los Bancos necesita de tener bases seguras sobre la riqueza que ha de entrar a fundar el crédito, i conocimiento exacto i preciso de los gravámenes que al tiempo de su establecimiento tiene la riqueza raíz ${ }^{28}$.

En su estudio de la economía del Valle del Cauca entre 1851 y 1880 , el historiador Richard P. Hyland opina: "Con la fundación del Banco del Cauca el 29 de noviembre de 1873 los diversos rasgos del cambio económico engendrados por la violenta ejecución de las políticas liberales de 1861 se consolidaron en la misma institución" $(1983,213)$.

\footnotetext{
${ }^{28}$ Informe del Ajente General de Bienes Desamortizados al Secretario del Tesoro, Imprenta de Echeverría Hermanos, Bogotá, s.e., 1875, pp. 9-10.
} 
Este es un caso específico en el que la desamortización creó el vacío de oferta de crédito que permitió la aparición de instituciones financieras modernas. La ley bancaria de 1865 hizo posible iniciar lo que se conocería como la era de la banca libre en Colombia (1870-1880) que se caracterizó por la libertad para ejercer el negocio bancario, la posibilidad de que cada banco emitiera sus billetes convertibles en oro y la ausencia de interferencias del gobierno (Meisel, 1992). El primer banco exitoso que se creó en Colombia fue el Banco de Bogotá en 1870, con un capital de $\$ 235.000$. Después lo seguiría, en 1875 , el Banco de Colombia (Meisel, 1990, 145). En general, el sistema bancario fue muy estable en este período, los bancos no emitieron billetes en exceso ni hubo grandes quiebras ${ }^{29}$. Cabe resaltar que el impulso que le dieron los radicales al surgimiento de la banca libre, vinculado con la desamortización, fue la base inicial de nuestro actual sistema bancario.

\section{¿FUE LA DESAMORTIZACIÓN UN BUEN NEGOCIO PARA LA NACIÓN?}

E1 historiador Fernando Díaz opinó: “Al final, con la firma en 1887 del Concordato, la Iglesia resultó victoriosa” (1984, 463). En el aspecto económico, el que aquí nos interesa, no fue cierta esa victoria, sino todo lo contrario.

En el Concordato firmado el 31 de diciembre de 1887 entre el cardenal Rampolla y el representante del gobierno colombiano, Joaquin F. Vélez, se establecieron las indemnizaciones que el gobierno colombiano reconocía por la expropiación de bienes durante el proceso desamortizador. $\mathrm{E} 1$ artículo 22 del Concordato dice:

E1 Gobierno de la República reconoce a perpetuidad en calidad de deuda
consolidada el valor de los censos redimidos en su Tesoro y de los bienes
desamortizados pertenecientes a iglesias, cofradías, patronatos, capellanías
y establecimientos de instrucción y beneficencia regidos por la Iglesia, que
haya sido en cualquier tiempo inscrito en la deuda pública de la Nación. Esta
deuda reconocida ganará sin disminución el interés de cuatro y medio por
ciento, que se pagará por trimestres vencidos (Ángel, 1935, 83).

En el artículo 24, la Iglesia condonó el valor del capital de los bienes que no se reconocieron dentro de otros artículos del Concordato y lo que se adeudara en ese momento por réditos o intereses vencidos. Por esta última condonación la Nación reconoció en el artículo 25 una compensación anual de $\$ 100.000$.

\footnotetext{
${ }^{29}$ Desde su creación, el Banco de Bogotá y el Banco de Colombia han figurado entre los más grandes del país y se han caracterizado por una gran estabilidad. En 1925, tenían el 24\% de los depósitos bancarios del país y estaban entre los cuatro bancos con mayores depósitos (Meisel, 1990, 159).
} 
En síntesis, la indemnización implicó dos pagos anuales a perpetuidad, uno por $\$ 100.000$ y otro del $4,5 \%$ de lo rematado o redimido. Si tomamos el valor de $\$ 15.362 .429$, que debe estar cerca del máximo que recaudó la Nación, se debieron pagar $\$ 691.309$ por intereses anuales. Si sumamos esta cifra a los $\$ 100.000$ del artículo 25 , obtenemos $\$ 791.309$, cerca de $\$ 800.000$. Para saber si la desamortización fue un buen negocio para la Nación es necesario traer a valor presente el flujo anual de los $\$ 800.000$ y compararlo con lo que recibió por la venta, apropiación para su uso y redención de bienes regidos por la Iglesia. Usaremos como tasa de descuento el $10 \%$, la que era usual para los préstamos es esa época (Meisel, 1990, 78); supondremos que la Nación recibió los ingresos de la desamortización en 1870, aunque recibió la mayor parte antes de ese año este supuesto sesga hacia abajo el cálculo de la rentabilidad de la desamortización; y para calcular el valor presente, tendremos en cuenta que de 1870 a 1887 no se pagaron intereses por los bienes desamortizados, y que los pagos anuales sólo se hicieron a partir de 1888, pues el Concordato se firmó en 1887 y el Congreso lo aprobó en 1888. Calculamos entonces el valor presente neto para la Nación por haber logrado la desamortización y por reconocer a la Iglesia como compensación un pago anual a perpetuidad de $\$ 800.000$ :

$V P N=\sum_{n=19}^{\infty} \frac{800.000}{(1+0.10)^{n}}=1.438 .870$

Cuando se compara el valor mínimo que pudo recibir la Nación por la desamortización, que aquí se calculó en $\$ 10,7$ millones, con el valor presente de la compensación, $\$ 1,4$ millones, sólo se puede concluir que la Nación hizo un excelente negocio gracias a la iniciativa de los liberales radicales. Ahora bien, durante la Regeneración se sustituyó la Constitución federalista de 1863 por la centralista de 1886. Con sus políticas económicas el país tuvo un papel moneda inconvertible a partir de 1886. Aunque ese dinero fiduciario no generó mucha inflación en los primeros años, desde comienzos de la Guerra de los Mil Días en 1899 se empezó a generar la inflación más alta en toda la historia del país. Entre ese año y 1903 la inflación promedio anual fue del 110\% (Meisel, 1994, 164). Por tanto, los pagos anuales que la Nación hacía a la Iglesia llegaron a ser irrisorios en términos reales. Paradójicamente, esta "segunda expropiación” corrió a cargo de los amigos de la Iglesia y enemigos de la desamortización, los conservadores y los liberales independientes. Con la reducción de la 
obligación anual por causa de la inflación, la desamortización reportó una mayor utilidad para el fisco.

\section{CONCLUSIÓN}

Analizamos el origen, desarrollo y culminación de la desamortización de bienes de manos muertas que realizó el ala radical del Partido Liberal cuando estuvo en el poder entre 1861 y 1885 . Ésta fue una de las grandes reformas económicas del siglo XIX por su magnitud y sus consecuencias. Durante la reacción conservadora y pro Iglesia Católica que siguió al período radical no se desmontaron las medidas que se habían tomado en este campo, sino que la Nación reconoció una deuda a favor de la Iglesia que, traída a valor presente y sin tener en cuenta que luego se redujo en términos reales debido a la inflación ocasionada por las políticas económicas conservadoras, resultó ser mucho menor, cerca del 13\% de lo que se confiscó. A pesar de ello, en la historiografía económica colombiana predomina una evaluación muy negativa de los efectos de la desamortización. En este trabajo argumentamos que la razón para ello es que en esa historiografía ha influido la retórica de la reacción conservadora, cargada de reproches, diatribas, acusaciones e imprecisiones ${ }^{30}$.

Insistimos en la importancia de las fuentes que se deben utilizar en el estudio de este tema. Buena parte de las notorias deficiencias sobre la desamortización en la historiografía económica colombiana se debe a que no se utilizan las Memorias de los secretarios del Tesoro ni los informes anuales de la Ajencia General de Bienes Desamortizados, ni se consultan las notarías. Una investigación que usó la información del Fondo de Bienes Desamortizados, existente en el Archivo General de la Nación, es la tesis de economía de Sergio Uribe Arboleda de 1976, que aún permanece inédita. Y sólo en trabajos sobre regiones, como los de Richard P. Hyland y Fernando Díaz, se ha usado la información de las notarías. Por la magnitud de esa información, las investigaciones con fuentes notariales y del Archivo General de la Nación tendrán que ser necesariamente por regiones y localidades. Si en el futuro se redactan muchas monografías sobre la desamortización en los antiguos Estados soberanos que, con un enfoque microeconómico, utilicen las fuentes primarias existentes, avanzaremos en la comprensión de los procedimientos que se usaron y de las consecuencias de una de las reformas anticoloniales más importantes del siglo XIX.

${ }^{30}$ Richard P. Hyland sostiene: "El efecto duradero positivo o negativo de estas reformas ha sido oscurecido por las guerras civiles que las acompañaron y por una tradición historiográfica fuertemente partidista” (1982, 371). 


\section{APÉNDICE}

La información sobre el valor de los bienes de la Iglesia Católica se tomó de Banzant (1971, 13); para la población de México se utilizó la que trae John Coatsworth para 1862 en Los orígenes del atraso, Nueve ensayos de historia económica de México en los siglos XVIII y XIX; para la población de Colombia se usó la de 1864 (Urrutia y Arrubla, 1970, tabla 9). El PIB per cápita de México se calculó como el 37\% del de Estados Unidos; el de Colombia se calculó como el 18\% del de Estados Unidos (Coatsworth y Taylor, 1998, 26); los gastos del gobierno federal de México se tomaron de Coatsworth (op. cit., 133); los gastos del gobierno federal de Colombia se tomaron de Pérez $(1883,197)$. Para calcular el valor de los bienes desamortizados en Colombia se supuso que todos los bienes se redimieron con bonos cuyo valor de mercado era un tercio de su valor nominal (lo que de acuerdo con diferentes informaciones es muy bajo, pues ese valor era por lo general cercano a la mitad). En ese descuento no se incluyó el millón de pesos que se recibió en efectivo ni los cinco millones en bienes que la Nación se apropió para su uso, o para el de algunas entidades de beneficencia o los estados.

\section{REFERENCIAS BIBLIOGRÁFICAS}

1. Ajente General de Bienes Desamortizados. Informe del Ajente General de Bienes Desamortizados, Bogotá, 1865, 1867, 1869, 1874, 1875, 1876.

2. Ángel, C. J. Constitución de la República de Colombia y Concordato celebrado entre el Gobierno de la República y la Santa Sede, Bogotá, ABC, 1935.

3. Archivo General de la Nación, Sección República. Fondo de Bienes Desamortizados, Rollo 1-30, s.f.

4. Banco Mundial. "Colombia: una política de tierras en transición", Documentos Cede 002126, 2004.

5. Banzant, J. Los bienes de la Iglesia en México, 1856-1875, México, E1 Colegio de México, 1971.

6. Camacho Roldán, S. Escritos sobre economía y política, Bogotá, Colcultura, 1976.

7. Caro, M. A. Del reconocimiento de los censos redimidos pertenecientes a capellanias, Bogotá, Imprenta de Vapor de Zalamea Hermanos, 1890.

8. Chiari, M. El metropolitano i su acusador, Bogotá, s.e., 1863.

9. Coatsworth, J. H. "Economic and Institutional Trajectories in Nineteenth-Century Latin America", J. H. Coatsworth y A. M. Taylor, eds., Latin America and the World Economy since 1800, Cambridge, Harvard University, 1998. 
10. Colmenares, G. "Censos y capellanías: Formas de crédito en una economía agrícola", Cuadernos Colombianos 2, 1974.

11. Cruz S., A. Historia Extensa de Colombia, Economía y Hacienda Pública, vol. XV, Bogotá, Lerner, 1965.

12. Deas, M. Del poder y la gramática, Bogotá, Tercer Mundo Editores, 1993.

13. Del Castillo, N. El primer Núñez, Bogotá, Tercer Mundo Editores, 1971.

14. Delpar, H. El Partido Liberal en la politica colombiana, 1863-1899, Bogotá, Procultura, 1994.

15. Díaz Díaz, F. La desamortización en Boyacá, Tunja, Ediciones La Rana y E1 Águila, 1977.

16. Díaz Díaz, F. “Estado, Iglesia y desamortización”, J. Jaramillo, ed., Manual de historia de Colombia, Bogotá, Colcultura, 1984.

17. Discurso del Presidente Provisorio de los Estados Unidos de Colombia en la instalación de la Convención Nacional, Bogotá, Imprenta de Echeverría Hermanos, 1863.

18. Estados Unidos de Colombia, Diario Oficial, 1864-1884.

19. Fazio, A. "Los efectos sociales de la desamortización de tierras en Colombia durante el siglo XIX”, tesis de magíster, Facultad de Economía, Universidad de los Andes, 2008.

20. Gobierno Provisorio de los Estados Unidos de Colombia. Actos vigentes, de carácter legislativo, del Gobierno Provisorio de los Estados Unidos de Colombia, Bogotá, Imprenta de Echavarría Hermanos, 1866.

21. Gómez, F. “Los censos en Colombia antes de 1905”, M. Urrutia y M. Arrubla, eds., Compendio de estadisticas históricas de Colombia, Bogotá, Universidad Nacional de Colombia, 1970.

22. González, F. "La reorganización de la Iglesia ante el Estado Liberal y su crisis", Historia general de la Iglesia en América Latina, Salamanca, Ediciones Sígueme, 1981.

23. Hera, A. de la. "Precedentes ilustrados del proceso desvinculador y desamortizador de bienes de manos muertas", H.-J. Prien y R. M. Martínez, eds,. El proceso desvinculador y desamortizador de bienes eclesiásticos y comunales en la América Española, siglos XVIII y XIX, Ridderkerk, Ridderprint, 1999.

24. Hirschman, A. O. The Rhetoric of Reaction, Cambridge, Belknap Press of Harvard University, 1991.

25. Hyland, R. P. "A Fragile Prosperity: Credit and Agrarian Structure in the Cauca Valley, Colombia, 1851-1887", Hispanic American Historical Review 62, 3, 1982.

26. Hyland, R. P. "Sociedad y economía en el Valle del Cauca", El crédito y la economía 1851-1880, Bogotá, Universidad del Valle y Banco Popular, 1983.

27. Jaramillo, R. L. y A. Meisel Roca. "Más allá de la retórica de la reacción. Análisis económico de la desamortización en Colombia, 18611888”, Cuadernos de Historia Económica y Empresarial 22, 2008.

28. Jaramillo Uribe, J. "Los Radicales", Credencial Historia 66, 1995.

29. Jaramillo Uribe, J.; A. Meisel y M. Urrutia. "Continuities and Discontinuities in the Fiscal and Monetary Institutions of New Granada, 
1751-1850”, B. Michael y R. Cortés C., eds., Transferring Wealth and Power from the Old to the New World, Cambridge, Cambridge University Press, 2001.

30. Liévano Aguirre, I. El proceso de Mosquera ante el Senado, Bogotá, Populibro, 1968.

31. Martí Gilabert, F. La desamortización española, Madrid, Rialp, 2003.

32. McGreevey, W. P. An Economic History of Colombia 1845-1930, Cambridge, Cambridge University Press, 1971.

33. Meisel Roca, A. "Los bancos comerciales en la era de la banca libre, 1871-1923”, A. Meisel et al., eds., Banco de la República. Antecedentes, evolución y estructura, Bogotá, Banco de la República, 1990.

34. Meisel Roca, A. "Free Banking in Colombia", K. Dowd, ed., The Experience of Free Banking, London, Routledge, 1992.

35. Meisel Roca, A. "Inflación y mercados cambiarios durante la Regeneración y la Guerra de los Mil Días, Un análisis econométrico", F. Sánchez, comp., Ensayos sobre historia monetaria y bancaria de Colombia, Bogotá, Tercer Mundo Editores, 1994.

36. Melo, J. O. "Las vicisitudes del modelo liberal", J. A. Ocampo, ed., Historia económica de Colombia, Bogotá, Siglo XXI, 1987.

37. Mosquera, T. C. de. Discurso del Presidente Provisorio de los Estados Unidos de Colombia en la instalación de la Convención Nacional, Bogotá, Imprenta de Echeverría Hermanos, 1863.

38. Nieto Arteta, L. E. Economia y cultura en la historia de Colombia, Bogotá, E1 Áncora Editores, 1983.

39. Núñez, R. La reforma politica en Colombia. Colección de artículos, Bogotá, Imprenta de La Luz, 1888.

40. Ospina Vásquez, L. Industria y protección en Colombia, 1810-1930, Medellín, Editorial Oveja Negra, 1974.

41. Pardo Pardo, A. Geografía económica y humana de Colombia, Bogotá, Tercer Mundo Editores, 1972.

42. Pérez, F. Memoria presentada al Presidente de los Estados Unidos de Colombia por el Secretario del Tesoro y Crédito Público, Bogotá, Imprenta de Gaitán, 1873.

43. Pérez, F. Geografía general física y politica de los Estados Unidos de Colombia, Bogotá, Imprenta de Echeverría Hermanos, 1883.

44. Prien, H. J. y R. M. Martínez de Codes. El proceso desvinculador y desamortizador de bienes eclesiásticos y comunales en la América Española, siglos XVIII y XIX, Ridderkerk, Ridderprint, 1999.

45. Ramírez, M. T. "Efectos de eslabonamiento de la infraestructura de transporte sobre la economía colombiana: 1900-1950”, J. Robinson y M. Urrutia, eds., Economía colombiana del siglo $X X$. Un análisis cuantitativo, Bogotá, Fondo de Cultura Económica, 2007.

46. Rausch, J. M. La educación durante el Federalismo, La reforma escolar de 1870, Bogotá, Instituto Caro y Cuervo, 1993.

47. República de Nueva Granada. Censo de población, Bogotá, Archivo General de la Nación, 1851.

48. Restrepo Uribe, J. "E1 romanismo es el catolicismo, o supremacía del pontífice romano”, Medellín, Imprenta Balcázar, 1865. 
49. Restrepo, J. P. La Iglesia y el Estado en Colombia, Londres, Publicado por Emiliano Salazar, 1885.

50. Rodríguez Piñeres, E. El Olimpo Radical, Bogotá, Talleres Librería Voluntad, 1950.

51. Secretaría de Hacienda. Memoria sobre la Hacienda Nacional presentada al Congreso, Bogotá, 1860, 1861, 1869, 1871, 1872, 1873, 1874, 1875, 1876, 1877, 1878, 1879, 1880.

52. Secretaría de Estado y Relaciones Exteriores. Actos Oficiales del Gobierno Provisorio de los Estados Unidos de Colombia, Bogotá, 1862.

53. Secretaría del Tesoro. Informe del Secretario del Tesoro y Crédito Nacional al Congreso, Bogotá, 1865, 1870, 1871, 1872, 1873, 1874.

54. Shaw, C. "Church and State in Colombia as Observed by American Diplomats, 1834-1906”, Hispanic American Historical Review 21, 4, 1941.

55. Sierra Mejía, R., ed. El radicalismo colombiano del siglo XIX, Bogotá, Universidad Nacional de Colombia, 2006.

56. Tirado Mejía, Á. Introducción a la historia económica de Colombia, Bogotá, E1 Áncora Editores, 1988.

57. Uribe Arboleda, S. "La desamortización en Bogotá, 1861-1870", tesis de grado, Facultad de Economía, Universidad de los Andes, 1976.

58. Vélez B., F. Datos para la historia del derecho nacional, Medellín, Imprenta del Departamento, 1891. 